\title{
Három Kapos menti község népének részvétele a katolikus egyház hivatalos jeles napi ünnepein, az 1930-as évektöl napjainkig
}

\author{
LANSZKI-SZÉLES GABRIELLA \\ Kaposvári Egyetem, Agrár- és Környezettudományi Kar \\ e-mail: lanszkine.gabriella@ke.hu
}

\begin{abstract}
LANSZKI-SzÉLES, G.: Participation of the people of three Kapos villages on the official celebration of the Catholic Church from the 1930 s to the present.

Abstract: Recollection of religious holidays in the villages of Gölle, Kisgyalán and Fonó was completed on a calendar year, focusing on the most important church holidays. During the celebration human relationships between the villages were important and are important even today. The celebration of the sanctified days of the church year has changed over the past century for both the Church and the faithful due to the change in lifestyle, attitude, and the growth of material goods.
\end{abstract}

Keywords: religion, church, sanctified days, lifestyle, tradition, celebration, village

Somogy megye Külső-Somogy kistájához, Kaposvár vonzáskörzetéhez tartozó szomszédos falvak, Gölle, Kisgyalán, Fonó községek az elmúlt századokban, mind munkájuk, mind ünnepeik során szoros kapcsolatot ápoltak egymással. Mindhárom község vallását tekintve római katolikus. „A cselédség Somogyban is szinte egységesen a katolikus felekezethez tartozott." Göllében, Fonóban, a Magyar Kegyes Tanítórendnek volt birtoka, Kisgyalánban a Festetics család volt a birtokos 1945-ig. Fonó, Kisgyalán, Gölle az Igali járásba tartozó középparaszti jellegű községek voltak.

„A dolguk után járó emberek az 1960-es évekig, legtöbbször egyik faluból a másik faluba gyalog tették meg az utat. Ezért a szomszéd falubeliek, egymás határait, dülőneveit nagyon jól ismerték, és legfőképpen jól ismerték, és ismerik egymás emberi tulajdonságait.” „A közösségek gondolatvilágát döntően befolyásolták a mindenkori gazdasági, társadalmi viszonyok. Minden egyes falunak más a lelkülete, még ha ugyanazon szempontok szerint szemléli is egy és ugyanazon ember, akkor is teljesen más jellemvonások domborodnak ki mindegyik közösségben. Ez az eltérő gazdasági adottságukkal is magyarázható" ${ }^{3}$ Gölle, Fonó, lélekszámban is vezettek Kisgyalán előtt. A háború előtt minden harmadik vasárnap miséztek Kisgyalánban, a másik két vasárnap át kellett menni Göllébe. Az 1960-as évekig minden második hétvégén, majd azt követően Kisgyalánban is tart misét a göllei plébános minden hétvégén. „Az 1960-as években Gyalánban a káplán tartotta a misét.”

Fonóban 1815-ben benediktálták a templomot, 1979tól Gölle látja el a lelkipásztori szolgálatot. Göllében a római katolikus templom barokk 1756-ban épült (1. és

Eperjessy E. 2006: 397

2 Lanszkiné Széles G. 2011/A: 112

3 Lanszkiné Széles G. 2011/B: 181.
2. ábra)." ${ }^{\circ}$ A három falu esetenként együtt tartja meg egyházi ünnepét. Jelen munkában, e községeknek a legfontosabb egyházi ünnepeinek ismertetése visszaemlékezések által történt. Az emlékek visszaidézésével összehasonlítottuk, hogy az emlékezet határától, napjainkig milyen változásokon ment keresztül az ünneplés módja, hogyan változtak a hagyományok. A szigorúan napján tartott ünnepek, sok esetben átkerültek vasárnapra. A ruházat is sokkal fontosabb szerepet töltött be, szinte csak egyházi ünnepek alkalmával vásároltak, varrtak új ruhát. Az öltözködésben is az ünnepi hangulat megteremtése volt az elsődleges. „Az Egyháznak a magyar néplélekre való hatása fölmérhetetlen. A nép készséges szívvel fogadta be tanításait, úgy érezte, hogy szolgái által Isten szól hozzája. Az evangélium magvetése nem hullott rossz talajra. Megfogant, gyümölcsöt hozott: életté, világnézetté, költészetté érlelődött." ${ }^{5}$

Az 1930-as években is - ahonnan a visszaemlékezésünk indul - még ez a kép tárulhatott volna elénk: „Dunántúlon lépten-nyomon egy-egy fehér torony emelkedik a falut rejtő lombok, a nádas, zsupp tetős házak közül. A templom körülette: a falvak szíve; ott az iskola, ott a plébánia. (...) A Dunántúlon; egyik község a másik mellett, alig egy-egy puskalövésnyire. A tornyok mind fehérek. Külsőre majdnem valamennyi egyformának látszik. Akár csak egy kaptára épült volna mind. A templomokat közelebbről nézve, látjuk, hogy a kizárólag hasáb alakra épült, a kaptafás-jezsuita stílusban tartott tornyokon még a torony sisakban legtöbb a változatosság; a sisak hosszúkás gúla (...), s a gömbökböl szökkenik fel a csúcs. A torony sisakja sok esetben bádogosmunka, de csak olyan gyakori a cserép, vagy fazsindelyes torony-tető is. Fatornyot ma már alig látunk egyet-kettőt (...) A kőben gazdag Veszprémben könnyű volt kőtemplomot építeni; a kőtelen Somogyban téglával építettek. (...) A Dunántúl legnagyobb része katolikus. Ezt mutatja a sok útszéli fakereszt.

A gazdagabb polgár vágyakozásának netovábbja, hogy szép kőkeresztet állíthasson háza elébe, a dűlőútra, «Isten dicsőségére», mint a keresztek fölirata mondja, de a maga nevét se szokta lefeledni a jó Isten neve; mellöl. Vízfolyások partján ott álldogál Nepomuki szent János képe, templomok táján az állatvédő, népszerü szent Vendel."” Írja Malonyai Dezső, A magyar nép müvészete című művében a 20 . század elején.

4 Szabó T., K. Goda Gy. 1984: 157

5 Bálint S. 1937: 13

6 Malonyai D.: A magyar nép müvészete - MEK mek.oszk.hu/ 01600/01671/html/index $\mathrm{htm}$ 


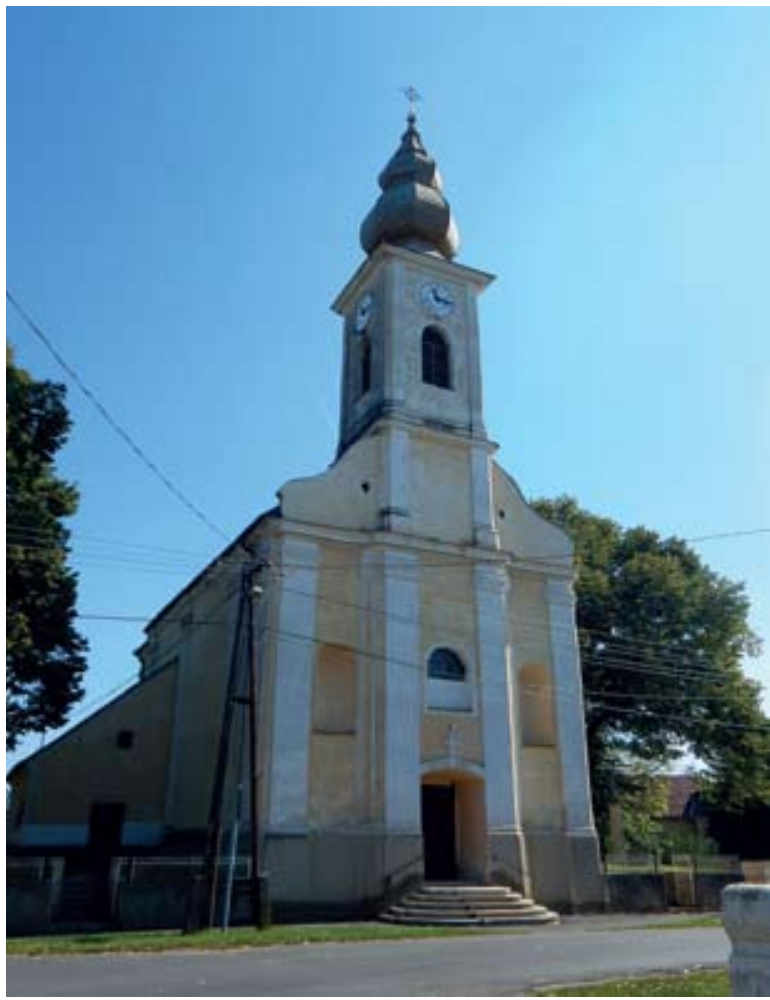

1. ábra. A göllei templom

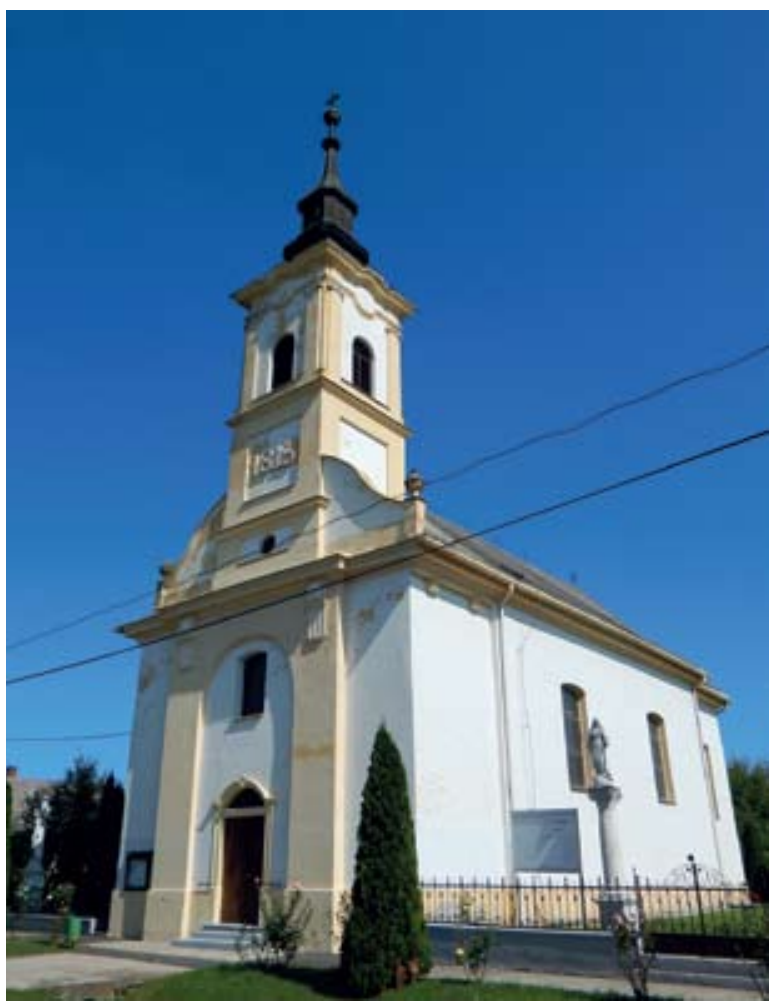

2. ábra. A fonói templom

Ugyanígy cselekedtek a fonóiak is. „Mi, fonói lakosok a batéi vasútállomásra gyakran gyalog mentünk, a lábbelink sáros volt, azt lecseréltük a vasútállomáson, az állomás melletti kocsmárosnak adtuk át, aki megőrizte, míg érte mentünk. Szívességből tette.”9 "Göllébe sokszor mentek, mennek a kisgyalániak, 2004-ben Fekete István Göllében történt újratemetésekor elmesélték az akkor 70-év körüli kisgyalániak, hogy helyismeretük révén a gyászmise végeztével, hogy kerültek elé rövidebb úton a temetési menetnek, hogy többet láthassanak a temetésből."10

Anekdota is szól azokból az időkből, amikor még „vasárnaponként a misét Göllében tartották. A müút ekkor még nem épült meg (1920-as évek), így az ember lábbelije, mire Göllébe ért szerencsés esetben poros, roszszabb esetben sáros lett. Így történt Vitéz Csima József és id. Széles Tóka József esetében is, akik komák voltak. Húsvétra rapsickodásból annyi pénzük összegyült, hogy kemény szárú csizmát tudtak venni, ami tudvalevő dolog, hogy ilyen csizma a grófokon kívül nem minden embernek adatott meg akkortájt. Ezért kellő becsben is tartották új szerzeményüket, erősen kaszálva, nagyra emelt lábbakkal, kerülgetve a friss harmatos füvet lépegettek Gölle felé. Bánták erősen a csizmát, bánták, hát nem akarták összesározni. Egy idő után azonban fárasztóvá vált az óvatos lépkedés. Egyikőjük megszólalt (melyikkőjük, az a mindenkori felidézés pillanatától függ), a rokonsági fok kapcsán elhangozhatott így is:

9 Jeli J. 1998: 36.

10 Lanszkiné Sz. G. 2011/A: 117. 118

$\begin{array}{ll}7 & \text { Fekete I. 1976: } 89 . \\ 8 & \text { Kovács Józsefné (Deres Teréz, 1937) szíves közlése. }\end{array}$ 


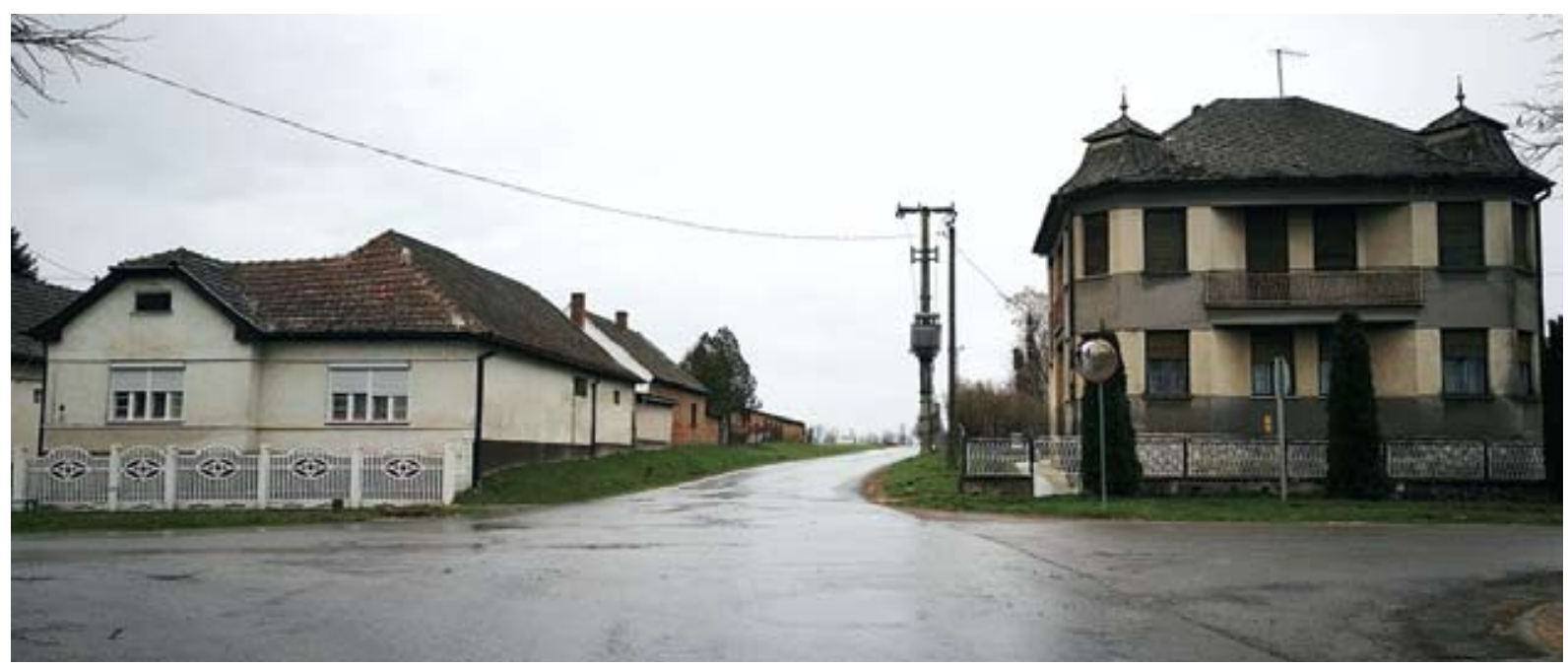

3. ábra. Gyaláni út

- Komám!

- Na?

- Cseréljünk csizmát!

- Cseréljünk! - Tehették, egyforma méretű volt a két csizma. A csere után, miután már egyikőjüknek sem a saját csizmájára kellett vigyáznia, tapodták a jó anyaföldet, tapodták. Egyikőjük sem törődött már a harmattal, mert sajátját ugye megbecsüli az ember, de a másé az már más.

A misére egyébként a lányoknak is csinosan illett menni. Mikor divatba jött az orkánkabát ${ }^{11}$ (ez már az 1950-es évek) akármilyen meleg is volt, "mese nincs”, fel kellett venni. Olvadoztak a lányok, olvadoztak, de nem vették le Göllébe érve sem a kabátot."12

„A kisgyaláni templom (4. ábra) országosan védett müemlék. A templom különleges alaprajzával - kívül ovális belül kör alaprajzával - tünik ki a tipikus körtemplomok közül. Az eredetileg fazsindely fedésű kupola tetejére építettek kis harangtornyot."13 „Mivel a község lélekszáma kicsi, nem a legtöbb faluban megtalálható típusúra építették, nem nagy befogadóképességűre tervezték. A göllei plébánia Canonica Visitátioja szerint 1781-ben építették újjá, míg a templomban látható latin nyelvű felirat piros betűkkel az 1737-es évet mutatta az építés évéül"14 $A$ kupola a 21 . században rézborítást, és új harangtornyot kapott.

A gyaláni templomról Fekete István a Ballagó időben említést tesz, amely szintén renoválásra utaló epizód. „Hova, hova? - kérdezte apám. - Csak ide Gyalánba uram. Egy asszony mondta a feleségemnek, hogy újra akarják cserepezni a templomot. Én cserepező mester vagyok uram."15

11 Az 1950-es évek végén az egyik lány édesapja, egész Pécsig ment az orkánkabátok megvásárlásának érdekében.

12 Lanszkiné Széles G. 2007: 238.

13 Kisgyaláni római katolikus templom (müemlék) | Somogyi Érték somogyiertekek.hu/somogyi.../kisgyalani-romai-katolikustemplom-muemlek.html

14 Olvasható Varga Gyula gyűjtésében (kézirat). Ott volt ez a római számmal felírt évszám, ahol most olvasható „Üdvözlégy Szent Kereszt, egyetlen reményünk" felirat az 1950-es évekig.

15 Fekete I. 1976: 263.

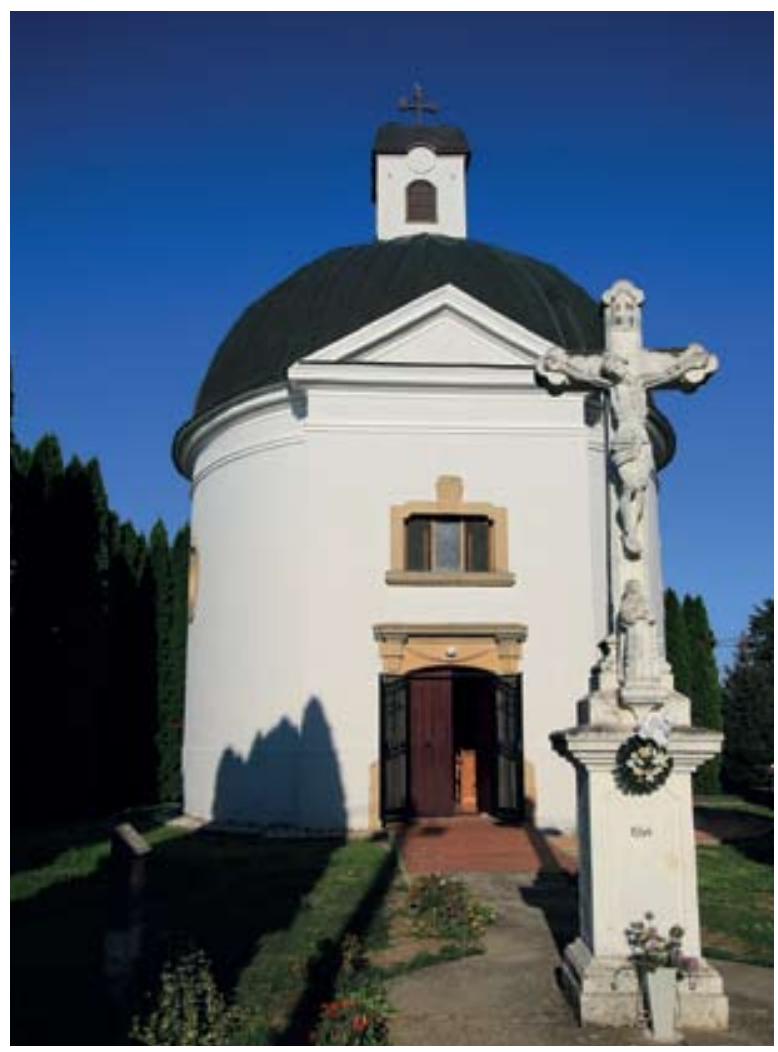

4. ábra. A kisgyaláni templom

Újabb tetőcsere az 1950-es években történt. „A tönkrement fazsindelyt keskeny palára cserélték, pedig a fazsindely megmentéséért a harkályok is mindent megtettek. Annyira korhadt, elöregedett volt a fazsindely, hogy csak úgy lüktetett az egész tető a piros sapkás fakopáncsok munkájától, akik belepték körbe-körbe a kupolát a kártevők gyüjtése közben."

Az 1950-es évekig a templombelső díszítésének a módja, ma már szinte elképzelhetetlen: „régen nemigen volt virágcserép a faluban, csak a demokráciában 
lett, ezért a piros muskátlik az 1950-es évekig piros, kék, körtemintás fazékba kerültek az oltárra." 16

Ezek után nem csoda, hogy a szintén az 1950-as években meginduló buszjáratról alkotott akkor 70 éven felüliek véleménye így hangzott, amit máig megőrzött az emlékezet.: „A Küs'ő soriak e’ mentek megnézni a buszt, nagy híre lett nekije, ki van ám világítva, ujjan vót mint a mennyország, mert sok lámpája volt. Minden újdonság volt, a be’ső soriak nem látták, mert lgalnak ment a busz elöször. Most meg üresen futkosnak az utcán a buszok."

A 19. század végén született emberek számára, az akkori kis falujuk szegényes viszonyai közt, amikor még a virágcserép is ritkaság számba ment, nem csoda, hogy a kivilágított busz is csodálatot keltett. A hozzátett záró mondat, pedig már a jelen helyzetet tükrözi. ${ }^{17}$

„A szegénység miatt, a „pusztai cselédgyerekektől, akik „mostoha körülmények között éltek”-, nem követelték meg a misére járást. Kinek nem volt jobb ruhája nem igen ment el misére.” „A pusztákról 1945-ig sem volt rendszeres a templomba járás. Oka részben a puszták több (esetenként 6-8-10) kilométeres távolsága, a megfelelő ruházat és lábbeli hiánya." ${ }^{18}$

„A cselédasszonyok között azonban volt aki a „falusi" viseletet követte. Ugyanolyan, esetleg szebb ruhatára is lehetett, mint egy szegény parasztnak. (...) A belinert az idősek még az 1980-as években is viselték fekete színben. Fiatal lányoknak fehér, drapp esetleg sötétkék illett. Ez a téli kabátot helyettesítette az 1930-as 1940-es években. A fejkendő viselet is az 1980-as évekig szinte kötelező volt az idősebb generáció számára. A templomban viselték legtovább a kendőt, a 70-80 évesek még hordták 2007-ben." ${ }^{19}$ Az 5., 6. és 7. ábrákon a misére menést örökítették meg az 1930, 1950, és 2007-es években, Kisgyalánban. A cselédasszonyok: „Selemkendőt (drapp színű brokát anyagból) templomba, vagy gyelös ünnepen és családi eseményen kötöttek. (...) Ebben az időben (az 1930-as években) már csaknem minden családban az imakönyv és a rózsafüzér is megtalálható volt. (...) Szokásban jött, a leányok számára bérmáláskor csontfödeles imakönyvet ajándékozott a keresztanyjuk." ${ }^{20}$ Csontfödeles imakönyv ajándékozása bérmáláskor jelenleg is szokásos. Tehetősebb parasztcsaládoknál az 1930-as években húszon felüli imakönyv is lehetett egy nagycsaládban, a háborúba menő férfi

16 „Manapság Pünkösdkor pünkösdi rózsa ha akkor épp virágzik, Úrnapján fehér virág, esküvők, keresztelök, temetések alkalmával az illetékes család viszi a virágot, ami legtöbbször rózsa, szegfü, gerbera, frézia, amarillisz, krizantém. Szépen összepászitották virágokat. Szombat délután történik a virágokkal való díszítés, és takaritás. Az ünnepekhez alkalmazkodik a virágdíszités a színekben is."

17 Autóbuszjárat megindítása, hogy községünket a megyeszékhelylyel összekösse. 1948. jul. 20. Kaposvár-Gölle közötti autóbusz részére garázs biztosítás. Egyházközség udvarán lévő kocsiszín javítása. Mivel a 3090 lelket számláló lakosságával, Gölle teljesen el van zárva a megyeszékhelytől. MNL Somogy Megyei Levéltár Szemelvények a közigazgatási iratokból, vegyes számadásokból (1866-1948).

18 Eperjessy E. 2006: 399.

19 Lanszkiné Széles G. 2007:157.

20 Eperjessy E. 2006: 226. 399.
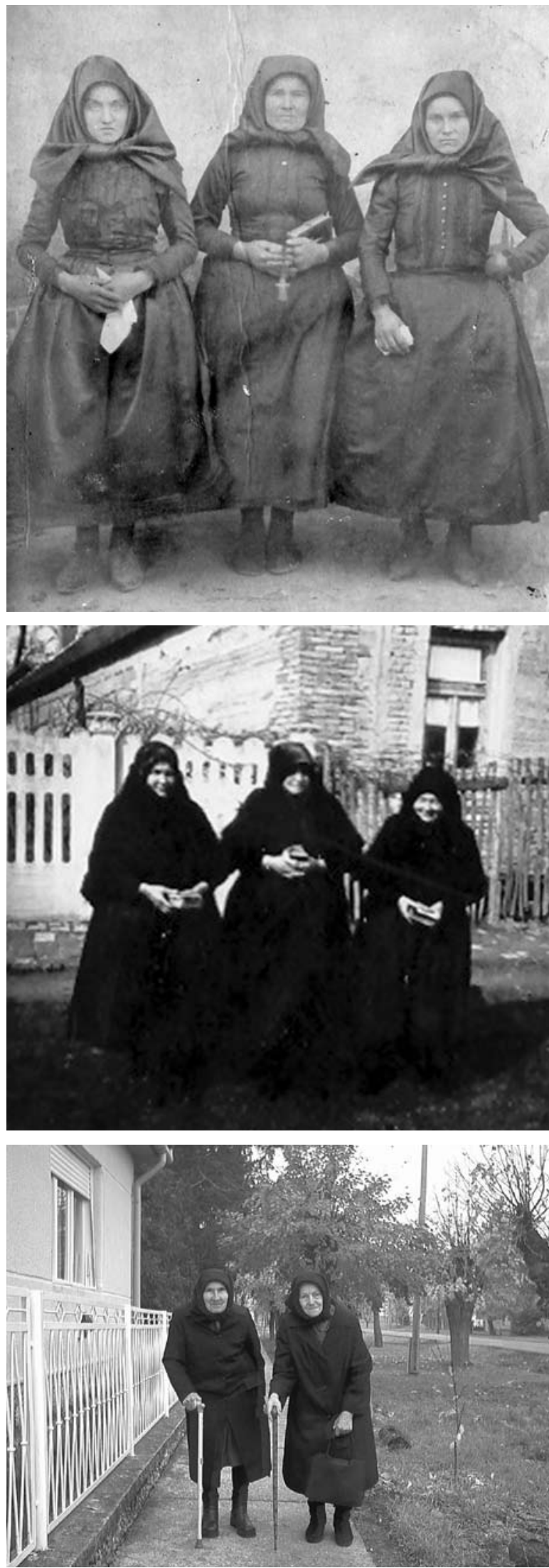

5-7. ábra. Misére menő asszonyok 


\section{HÁROM KAPOS MENTI KÖZSÉG NÉPÉNEK RÉSZVÉTELE A KATOLIKUS EGYHÁZ HIVATALOS JELES NAPI ÜNNEPEIN, AZ 1930-AS ÉVEKTŐL NAPJAINKIG}

imakönyvétől, a gyermekek imakönyvéig. A legkorábbi fényképen olvasó, rózsafüzér, zsebkendő is látható az imakönyv mellett.

„A templomban az ülésrend a következő volt: nálunk nem a vagyoni helyzet, hanem a kor, és a nem határozta meg. A pap két oldalán balról a kisfiúk, jobbról a kislányok, a lépcsőn felül a kicsik, utána a nagyobbacskák álltak, ott ahol jelenleg a kisoltár található.

A kisoltárt Wirth János akkori plébános, (jelenleg esperes) készítette a 1980-as évek közepén. A göllei templom áldoztató vasrácsából alakította át, mivel szakmája lakatos. Jelenleg a gyerekeknek két kispadot helyeztek el elöl. Az 1950-es évekig a padsorok között középen álltak a nagylányok, mögöttük a fiatal menyecskék, míg „teherben nem maradt”, akkor leülhetett. „A padokban elöl ült a fiatalabbja, hátul az idősebbje.” A kórusban fent a férfiak és a legények álltak a karzatnál. $A z$ orgonánál ült a kántor és a tanító. Csupán az intéző és a felesége ült párban elöl az oltárnál. Ma is a nők helye lent padokban van, a férfiak fent a kórusban tartózkodnak. Régen a gyerekek, nők nem mehettek fel a kórusba, ez a kitétel ma már nincs meg. Még a 2000-es évek elején is megszólták azokat a nőket, akik felmentek a kórusba.

„A templom elött elhaladva háromszor kellett keresztet vetni, a nagy kökeresztnél, a templom nyugati bejárójánál levő kereszt elérésekor, és az oltár magasságában a keleti részen. Amikor a templom déli oldalán levő járdán mentünk. "21

„A magyar parasztság életében az ünnep jóformán egyet jelentett az egyházi év megszentelt napjainak ünneplésével. Az évkezdő adventtől az évzáró András-napig sok ünnepe és jeles napja volt a katolikus egyháznak."22 Az ünnepekre való visszaemlékezést a naptári évhez kötődően készítettük el, a legfontosabb egyházi ünnepekre összpontosítva. A falvak közötti emberi kapcsolatok is fontosak voltak, és fontosak ma is az ünneplés során is. Az egyházi év megszentelt napjainak megünneplése, az életmód, szemléletmód váltásnak, valamint az anyagi javak gyarapodásának köszönhetöen változott az elmúlt évszázad során, mint az egyház, mint a hívek részéről. Kiragadott példákkal jól szemléltethető: Most már a nők is felmehetnek a kórusba. A padok sarkában már nincsenek zászlók tüzve. „A legtöbb házban nagycsaládok éltek együtt: csak úgy özönlött ki a nép vasárnap az utcára, mikor elindultak a misére." Ez ma már nincs így.

„Arra is volt példa, hogy a Plébános Úr nem áldoztatta meg a körösztanyámat, mert végeredményben összeállt a M. Vendellel, de a M. Vendelt megáldoztatta! (1950-es évek). Körösztanyám szégyenkezett. Más megítélés alá esett egy nő, mint egy férfi. Most már áldozhatnak házasság nélkül is." Enyhülnek az elöítéletek.

Szégyenkezni lehetett a rongyos tutyitalp miatt is. „A tutyit kötötték, vagy posztóból készítették, vászonnal talpalták. A vászontalpalás, nagyon hamar leszakadt, így minden estefelé „tutyitalpalás” volt a „téma”,

21 Lanszkiné Széles G. 2007: 173

22 A katolikus egyházi év ünnepei A magyar parasztság életében ..hunyadilaca.hu/zene/segedanyag/egyhazi_unnepek.pdf ugyanis megszólásra adott okot, ha valakinek rongyos volt a tutyija talpa. Már pedig ez hamar kiderült, hiszen a templomban le kellett térdelni." ${ }^{23}$ Ma már tutyitalpalás sincs, kézzel harangozás sincs. Gombnyomásra történik a harangozás, már nem kell kötelet húzni sem.

„Érezni kellett a kötelet harangozáskor, a kicsi lélekharang nagyon vékony hangú meg kellett szakitani a harangozást, ha idősebb halott volt hosszan harangoztak." Sajnos többször volt ok a harangozásra. „Harsányiék elvitték Göllébe a gyereket gyónni, és megfázott a szánkón tüdőgyulladást kapott," ma már a fütött templomokban ilyen eset nem történik meg.

Közösen történt az oltárterítők hímzése is, ma egy valaki hímzi, vagy tovább adják a következő asszonynak, aki tovább hímzi az oltárterítőt egyedül, abban az esetben, ha nem készen vásárolt. Az 1930-as években a hímzés még együtt történt: „Pintér tanító az iskolába odahitta az asszonyokat, és rózsaszín, bordó rózsás oltárterítőket hímeztek." Sajnos az új előnyben van részesítve a régivel szemben: „Nem akart elférni, ezért a legrégebbieket elégettük."

\section{Az egyházi év naptári év szerinti ünnepei}

Kisgyalánban az egyházi év ünnepeire a visszaemlékezés Bóna Lászlóné (Széles Rózsa) Nagynéném segítségével történt, ezért az Ő mondatai dőlt betűvel íródtak, és ekkor nincs hivatkozás.

\section{Január 6, Vízkereszt}

„Vízkereszt vagy háromkirályok napjával zárul a karácsonyi ünnepkör és kezdődik a farsangi időszak. (...) A víz megszentelésének, azaz megkeresztelésének szertartásából ered a magyar vízkereszt elnevezés. A szenteltvíznek mágikus ereje, gyógyító, gonoszűző, rontást megelőző szerepe volt. A víz és tömjén szenteléséből alakult ki a házszentelés." ${ }^{4}$

„Bemutatták Jézust a templomba. Ha hétköznapra esett, akkor is napján ünnepeltük meg, most már rátették vasárnapra, van neki már jó pár éve, hogy vasárnap ünnepeljük. A kommunista világ elnyomta a vallást.

Gyalog mentünk át Gyalánból Göllébe, akármilyen hideg is volt. Volt, hogy nagyon fújt a szél, a templomban is nagyon hideg volt, szinte megfagyott a combom, a templomban engedett fel.

Szerettünk csinosan felöltözködni, az ember kívánta az ünneplős ruhát amikor már kezdtünk nagylánykodni. A tanitó elengedte az iskolából, aki menni akart ekkor a misére Göllébe. A gölleiek minket néztek, mi meg a gölleieket."

Új ruha vásárlása elsősorban egyházi ünnepek alkalmával került sor, feltámadásra, elsőáldozásra, bérmálásra, búcsúra. Most is elhangzik alkalmanként: „ez a misére járó ruhám.” Az 1970-90-es évek közötti időszakban is nagyon fontos volt mindenki számára hogy a megjelenés méltó legyen az ünnephez. Manapság már előfordul farmer, póló és dzseki viselése is a szentmisén.

23 Lanszkiné Széles G. 2011/B: 193. 194.

24 Tátrai Zs. Molnár E. 1997: 30. 
Házszentelésre e három községünkből, jelen évekből nem tudunk példát hozni, azonban az ország más tájegységein még élő hagyomány. „Hazaérkezve, egyik családtag fölírja az ajtóra a $\mathrm{G}+\mathrm{M}+\mathrm{B}$ betűket, majd megszentelik a házat.(...) Ezt nem törölik le sokáig."25 2018-ban is Mezőkövesden számos család kérte házának újra szentelését.

\section{Február 2, Gyertyaszentelő}

„Már 7. században a keresztények gyertyákkal a kezükben dicsőítő énekeket és zsoltárokat énekelve, a templomok és a szent helyek körül körmeneteket tartottak. (...) A szentelt gyertya, mint Krisztus jelképe egyike a legrégibb szentelményeknek." 26

„Pirosbetüs ünnep volt, utóbb vasárnapra tették. Minden ünnepnek volt éneke. Valóságos ünnep. Ha hétköznapra esett, akkor is volt menetel Gölléébe misére. Az oltárra vitték a saját gyertyát, amikor a szentelés után kimentek érte mindenki megismerte a saját magáét." Manapság mindenkit a padon vár a saját szentelt gyertyája, egy kis körgallérral védve, a viasz elleni lecsepegéstől.

A megszentelt gyertyát mindenki megőrzi. „Régen a szentkép alatt a falra szögre akasztották a gyertyát, és két rózsaszín szalaggal átkötötték.” "Liturgikus színek jelentésében a rózsaszín az öröm színe."27 „A nép azonban még érzi a szimbolikus ábrázolásból áradó jelentést, az ő múvészi felfogásával egyezik az egyházi müvészet alkalmazottsága. Minden templomi képnek, tárgynak a vallásos gyakorlatban rendeltetése, szerepe van éppen úgy, mint az ő művészi módon kiképzett környezetének." 28 „Majdnem minden háznál volt szentkép (8. ábra). ${ }^{29}$ Mindenki törekedett, hogy valamije legyen. Kaposváron ahol most a nagy buszmegálló van, volt az asszonypiac, ahol a szentképeket árulták, hitvány kis helység volt. Két szentképet tettek egymás mellé, vagy dupla képet ami nagy kép, 2 ágy fölé való. Az 1880as években Mária viasz szobra volt felöltöztetve üveg keret mögött.” „Kegykép, ill. -szobor másolatai számára készített szekrényke, mely a sarkos elrendezésü parasztszobák asztalszögletében, a szentsarokban függ vagy a sarokpadhoz építve áll. (...) Általában a templom kegyképéhez hasonlóan felöltöztetik, virág girlanddal veszik körül, a házat mintás papírral, ezüstfóliával vagy szentképekkel bélelik.”30 „A 19. század második felében az ország nyugati területének katolikus lakossága körében teret hódított a polgárosodó parasztság tisztaszobáinak szent sarkát díszítő „Mária-ház” divatja. A szobrot az asszonyok öltöztették fel színes ruhácskákba, mellé tették a lányok menyasszonyi koszorúját és a vőlegény bokrétáját, majd szentképekkel és müvirággal díszítették. Ez rendkívül színes és gazdag

25 Bálint S. 1989: 151.

26 Tátrai Zs.- Karácsony Molnár E. 1997: 41.

27 Liturgikus színek - Magyar Katolikus Lexikon. lexikon.katolikus.hu 28 Bálint S. 1937: 11. 12

29 Bóna Lászlóné (Széles Rózsa) látható a fotón, visszaemlékezés közben. A szobában szentképek, és a saját készítésű díszpárnák is találhatóak.

30 Mária-ház - Magyar Néprajzi Lexikon /mek.oszk.hu/02100/02115/ $\mathrm{html} / 3-1561 . \mathrm{html}$

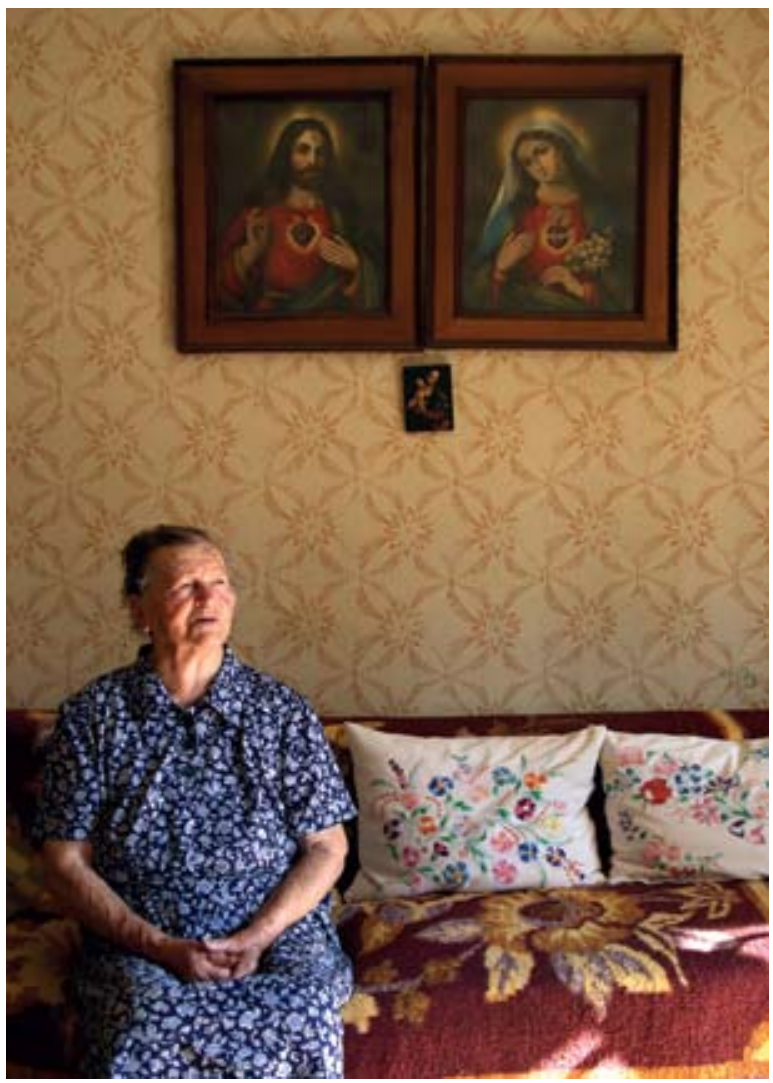

8. ábra. Bóna Lászlóné (Széles Rózsa) visszaemlékezés közben

látványt nyújtó kompozíció." ${ }^{31}$ Kisgyalánban az 1970 es évek közepén még volt ahol díszítette Mária ház a házat. $\mathrm{A}$ kisgyaláni templomban is található két Mária ház lourdes-i Mária, és gyüdi Mária. (9. és 10. ábra). Az ízlésvilág változásnak köszönhetöen kevésbé látható helyen vannak jelenleg elhelyezve. „Ezek a képek a selyempapír virágokkal már avéttak." Eredeti helyükön faragott stáció képek kerültek elhelyezésre.

„A hagyomány szerint vihar ellen hatásos a szentelt gyertya, ha villámlik, nagy vihar van, akkor kell meggyújtani a szentelt gyertyát."

„Nincsen katolikus parasztház, ahol ne volna. Rendesen a sublót-, vagy ládafiában tartják, vagy pedig felöltöztetve a falra akasztják, hogy föképpen vihar idején meggyújtsák és imádkozzanak mellette." ${ }^{2}$

2018-ban Gölle, Kisgyalán, Fonó, hívei együtt ünnepelték meg Gyertyaszentelő ünnepét. A kisgyaláni, fonói falubuszok átvitték a híveket Göllébe a misére. Az elmúlt évtizedekben mindhárom község külön, saját falujában celebrált misén ünnepelt.

\section{Február 3. Balázs-áldás}

„Szent Balázs püspök ünnepe, torokfájás elleni áldás."

„Fonóban különösen kiemelt tisztelettel ünnepelték: „A február 11-hez kötött ünnepet a lourdes-i jeleneteket,

31 Selmeczi Kovács A. 2014: 234. 235

32 Bálint S. 1937: 167 

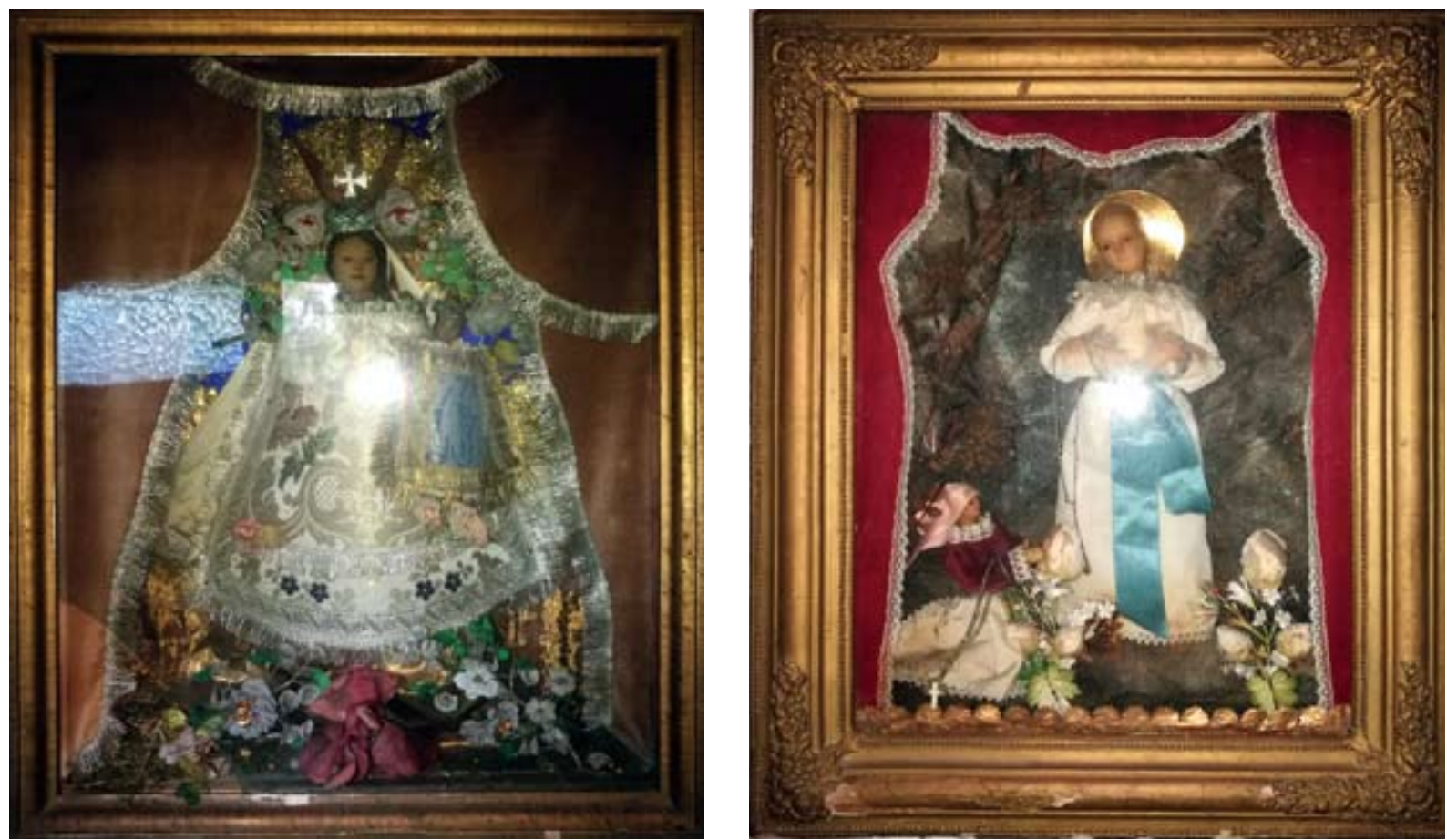

9-10. ábra. Gyüdi Mária, Lourdesi Mária Mária házban

az asszonyok kilenc napig közösen a lourdes-i szobrokat kirakták a katedrára az iskolában vagy valamelyikük otthonában, és együtt imádkoztak. Megemlékezve arról, hogy 1858. február 11-én megjelent a Boldogságos Szűz Soubirous Bernadette-nek. Fonónak fogadott ünnepe nincs.

Az ünnepélyek méltó rangot kaptak a hétköznapok sorában, legyen az állami, egyházi vagy más jellegü ünnep. Március 15-ére müsorral készültek a gyerekek az 1940-es évek végéig." 33

„Érdekes feljegyzés az átmeneti korszakból: 1946. márc. 5. Márc. 15-ei ünnepély megrendelése.

1. Mise 9-kor

2. Himnusz

3. Megnyitó beszéd. Tartja: Világos Ödön.

4. Szavalatok

5. Ünnepi beszéd. Tartja: Berta Lajos

6. Szavalatok

\section{Szózat}

1946. ápr. 4.: Ünnepi mise, majd utána program szerinti ünnepség, amelyet mindkét helyen (Kisgyalán, Gölle) a nemzeti bizottságok állítottak össze."34

\section{Hamvazószerda}

„A nagyböjt a keresztény egyházban a húsvéti előkészület ideje, böjtöléssel, egyházi és népi ájtatosságok végzésével. Jézus 40 napi böjtölésének és kínszenvedésének emlékére tartják. (...) Hamvazószerdától húsvétvasárnapig tart, utolsó előtti hete a virághét, amely a virágvasárnappal zárul Ezt követi a húsvétvasárnapig

33 Lanszkiné Széles G. 2013/A.: 159

34 MNL. SML. Szemelvények a közigazgatási iratokból, vegyes számadásokból (1866-1948) tartó nagyhét.” ${ }^{35}$ „Húshagyó vasárnap után 40 nap böjt. Homlokra hamuzás, a tanító elengedte a gyerekeket az iskolából, mivel a napján szerdán tartották, most vasárnap van a hamvazkodás. Nagybüjtben húsevés egyáltalán nem volt!"

\section{Virágvasárnap}

Fekete István így emlékezik vissza: „Virág vasárnap előtti hétfőn azt mondja barátom, Puska Péter, hogy eddig nem beszélt róla, most elárulja, hogy a Potyondymalom elött, a nádasban talált egy különös füzfabokrot, amelyen akkor még nem nyíltak ki a barkák, de ha kinyílnak, akkorák lesznek, mint egy-egy szem nagy dió... - Más nem tud róla - mondta Péter jelentőségteljesen, s én már majdnem esküre emeltem kezem tőlem nem is tudja meg senki... de erre már nem volt szükség, mert Péter hozzátette még: - Neked elmondom, mert tudom, hogy te nem vagy olyan... Barátom bizalma mélyen meghatott, mert a tavalyi virágvasárnapom úgyis teljesen elromlott. Az történt ugyanis, hogy Tóka Józsi bácsi, aki a passióban Jézust énekelte, a szenteléskor kihúzta kezemből a barkát és magasra tartotta, hogy el sem vehettem töle (...) A haragtól már könnyem csordult (...) amikor megláttam Jóska bácsi bütykös, csizmás nagy lábát közvetlen a pad éles lába mellett, s az orgonapadon abban a pillanatban nem ült senki (...) és nem is vette észre senki, hogy a padot én pár centivel idébb húztam, hogy a lábak Jóska bácsi lábánál legyenek. Ha a mester - azaz apám - leül a maga nyolcvan kilójával... ami a következő pillanatban már meg is történt és Jézus-Tóka Jóska bácsi szemei a fájdalomtól majd kiugrottak. - Mester úr! Mester úr, az Istenért, szálljon

35 Tátrai Zs. - Karácsony Molnár E. 1997: 82. 
le a lábamról... Jézus-Tóka Jóska bácsi az nap majdnem ölben vitte haza bal lábát... s erre gondolva (...) remélhetem, hogy az idén a virágvasárnap - Péter csodabarkáival - jobban sikerül.... - Holnap reggel meg is szedhetnénk - mondta Péter - már majdnem egy hete láttam s eddigre biztosan kinyíltak."

„János evangéliumában így ír:”Jézus Jeruzsálembe jő, pálmaágakat vőn és kiméne elébe, és kiált vala: hozsánna!" Ahol a pálma a kedvezőtlen éghajlat miatt nem él meg, más növényekkel helyettesítik: puszpánggal, tiszafával és füzfaágakkal. Közép-Európában, s így nálunk is, a kora tavasszal virágzó füzfaág, a barka helyettesíti. A nap magyar elnevezésében is ez a tavaszi ághoz, virágzáshoz való kapcsolódás jelenik meg." A barkás füzfaágakat szenteli be a pap, ezzel vesznek részt a hívek a körmeneten, majd hazaviszik, megörzik." ${ }^{6}$

„Virágvasárnapi bárkaszentelés egyházi eredetű népszokás ugyan, de a szentelt barkát felhasználták rontás ellen, gyógyításra, mennydörgés, villámlás elhárítására is. sokfelé élt az a hiedelem, hogy a szentelt barkát nem szabad bevinni a házba, mert elszaporodnak a legyek és a bolhák, a tojásból nem kelne ki a csirke." 37 „Mert büjt lilában teszi a pap a misét. A bárkaszentelés napja, Húsvét előtti vasárnap. Azért kell hazavinni a két szentelt bárkát, hogy a villám ne csapjon a házba."

2018. január elején az enyhe télnek köszönhetően, a kaposvári piacon már barkát árultak, ezt elmondtam 88 éves nagynénémnek Kisgyalánban, mire Ő: „Akkor el kell mennem a halastóra bárkát szedni, mert ha már most van, akkor mire a bárkaszentelés lesz, addigra már elnyílik." Mivel Ő szokott gondoskodni a barkáról minden évben, és ehhez előre látásra is szükség van, az időjárás, és maga az ünnep ideje is befolyásolja, hogy a barka épp nyílik-e virágvasárnap.

Szántai Árpádné (Bank Rózsa 1926) kivitte a temetöbe a barkát az 1980-as években, amire azt a tanácsot kapta, hogy „inkább vigye haza tüzze a rag alá, mert jó villámcsapás ellen." Szót is fogadott haza is vitte. Valószínűleg édesanyja még kivitte a temetőbe a barkát, erre emlékezve tette Ő is. Azonban ez a hagyomány, hogy valóban miért szokták kivinni a temetőbe a barkát már a feledés homályába veszett Kisgyalánban. Ő volt az idősebb, azonban a meggyőző érvelésre a „fiatalabbtól" (1930) elfogadta az újabb keletű hagyományra vonatkozó tanácsot. Még régebbi hagyomány szerint, „Somogyban a barkát sírhalomra tüzik, hogy a vakondok ne túrja fel. (...) A virágvasárnap megszentelt ciróka (barka) egyrészét Kéthelyen tűzre teszik, hogy füstje megakadályozza a villám lecsapását. Másik részét húsvét napján a mezőre viszik, letüzdelik, hogy a jég elkerülje a vetéseket. Ilyenkor mindenfelé térden állva ájtatoskodó embereket látni a földek között." ${ }^{38}$ „Ha az új ház építésekor, túr fel a pucok (vakond) akkor nemsokára halott lesz a háznál." A hagyományok szövevényében ezt a szokást még ismerik Gyalánban, annál is inkább, mert példát is tudnak hozni rá, az elmúlt száz évből.

36 Tészabó J. 2011: 7.47

37 Tátrai Zs. - Karácsony Molnár E: 1997: 88.

38 Bálint S. 1937: 80
„Minden sírt rendbehoznak. Azokét is, akiknek már nincs családbeli gondozójuk. Végül a sírokra barkacsokrot raknak."39 Az 1990-es években Kisgyalánban még szokás volt azoknak a síroknak a rendbehozatala, ahol nem volt hozzátartozó.

Érdekes egy-egy hagyomány jellegének megváltozása. Gyerekkoromban, az 1970-80-as években, nem vittük be a barkát a házba, hogy nehogy „ne keljenek $k i$ a csibék tojásból.". A gondolkodásmód megváltoztatja az adott hagyományt, ha már „idejét múlttá vált.” Amióta, nincs otthon keltetve csirke azóta, díszítheti barka a lakást, hiszen nem nullázza le a kelési százalékot a barka jelenléte a házban.

„Virágvasárnap az igali bábos kirakódott Göllébe', de Gyalánba' is megállt a bábos a kocsival.” „Pékek, sütők a városiasodó helyeken voltak többen (Szigetváron négy (két pék, két sütő), Kaposváron 3, Igalon, Nagyatádon, Tabon 2-2."40 Igalban a 20. században is müködött tovább a bábos.

„Húsvétra a bábostól vett bábló, bábbaba, volt a húsvéti ajándék, de nem a saját gyerekek számára, hanem a komaasszonynak, vagy az Ö gyerekének. Párosan illett vinni az ajándékot minden évben. Nem volt ám rá pénz, hogy a saját gyereket is ellássák bábkenyérrel az 1930 40-es években!" Azonban az 1970-es években már az itthon maradt gyerekek az Andocsi búcsút a rózsaszín, és citromsárgaszínü bábolvasókkal társították.

„A gyerekeknek szánt búcsúfia közül a mézeskalács, különösen pedig a mézeskalácsból készült olvasó a legáltalánosabb. (...) Nem lehetetlen, hogy a mézeskalács valamikor kultikus eledel, eulógia, vagyis szentelmény volt. Erre utal az a mézeskalácsosok között élő hagyomány is, hogy ezt a mesterséget a barátok találták ki." ${ }^{41}$

\section{Nagycsütörtök}

Elmentek a harangok Rómába, a haragok ettöl a naptól nagyszombatig nem szólaltak meg, hanem a kereplő volt hívatott hangot szolgáltatni. Göllében egyszerübb kézi kereplő volt (11. ábra). Kisgyalánban a kereplő (12. ábra) hengereinek bütykei lecsattantak, ez helyettesítette a harang hangját Gyalánban. A kereplő a községházán (ma Coop bolt) volt elhelyezve, háromszor szólaltatták meg naponta, csak csattogott, ezért a külső sorban nem hallották, csak a templom körül volt halható. „A csörgőről ${ }^{42}$ és a kereplőről feltételezik, hogy alkalmasak a gonosz szellemek elűzésére." 43

„A fakereplőt még az 1960-as években is használták, kiváltság volt azt működtetni."44 „Lányok is hajthatták, úgy kellett hajtani, mint a répavágót." Ez a fakereplő az idők során „elveszekelődött."45 2007-ben ezt a választ kaptam a kereplő hol létét illetően. Azonban a későbbiek során, amikor szóba került a kereplö, akkor

\footnotetext{
39 Bálint S. 1989: 202

40 Knézy J. $2013: 257$

41 Bálint S. 2009: 116.

42 Az 1970-es években még betlehemezéskor láncosbotot csörgettek a gyerekek, majd lassan „lekopott” a lánc a botról.

43 Rosta E. Rábai A. 2007: 229

44 Dr. Szabó Gyula szíves közlése

45 Várkonyi I. 1988: 62. Tönkremegy, elkallódik, csak tárgyra vonat-
} kozik. 


\section{HÁROM KAPOS MENTI KÖZSÉG NÉPÉNEK RÉSZVÉTELE A KATOLIKUS EGYHÁZ HIVATALOS JELES NAPI ÜNNEPEIN, AZ 1930-AS ÉVEKTŐL NAPJAINKIG}

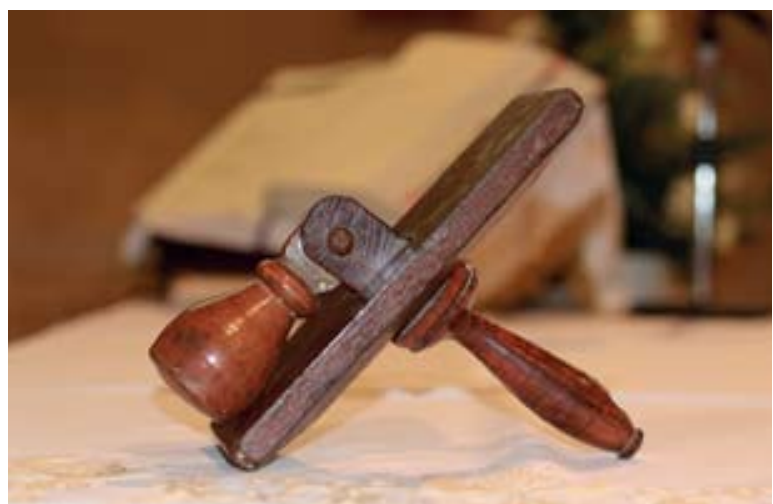

11. ábra. A göllei kereplő

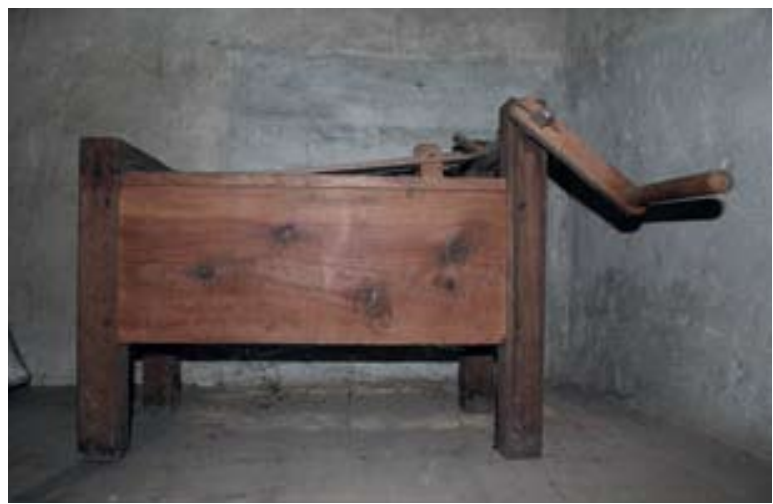

12. ábra. A kisgyaláni kereplő

kiderült, hogy átkerült Göllébe. Annál az egyszerü oknál fogva, hogy a községházából élelmiszer bolt létesült, így a kereplő mivel a gyaláni templomban nehezen fért volna el ezért került át Göllébe. Mindegyik falu természetesen arra emlékszik jobban amit tőle vittek el. A gölleiek ugyanígy emlékeznek arra, hogy az áldozórács viszont tőlük került Gyalánba, sőt még Kaposvárra is vittek belőle.

\section{Nagypéntek}

A szertartás ${ }^{46}$ 2017-es évben Kisgyalánban volt, A gölleiek jöttek át autóval Kisgyalánba. Azért volt Kisgyalánban mert itt valószínüsíthető volt, hogy többen lesznek a szertartáson.

„Nagypénteken nem volt szokás tüzet rakni.”,A nagypénteki böjt abban is megnyilvánult, hogy minél később kezdték el a főzést, mert a babona szerint, aki először tüzet gyújtott, oda mentek mind a nem kívánatos férgek bogarak. Ezért lesték a gazdaasszonyok, kinél száll már a füst, hogy ők is nyugodtan neki kezdhessenek." 47

„A római katolikus egyházközségekben hagyomány a Szent Sír templomi felálítása, vagy ahogyan Somogyban általában mondják Isten koporsójának az imádkozással való őrzése. Az iskolás gyerekek - fél óránként váltva egymást - térdepelnek előtte, de a felnőttek is eljönnek a templomba. (...) Göllében a nagypénteki pas-

46 Szertartás, és nem szentmise mert az oltárfosztás miatt nincs oltárterítő.

47 Knézy J. 1975:112. sió eléneklése után a nagyszombat esti feltámadásig az asszonyok „Istent csókúni” mentek a templomba. Az oltár alatt egy kihúzható koporsóban feküdt az Úr Jézus szobra. Ezen alkalommal a hívek pénzt is adományoztak a templomnak." ${ }^{8}$ Göllében 2018-ban hófehér szegfüvel történt Krisztus koporsójának feldíszítése (13. ábra).

Kisgyalánban az 1980-as évek második feléig volt hagyomány a Jézus csókolás, itt nem lévén Jézus koporsója Jézus szoborral, a következőképpen történtek az előkészületek: „Vittem a vánkost ${ }^{49}$, fehér lepedőt és az oltár előtti dobogóra leterítettem a lepedőt és rátettem a vánkost, és ráfektettem a keresztet, Jézus feje alá került a vánkos. A kereszt végében egy kis hoszszúkás bádogtálca volt, ebbe lehetett dobni a pénzt. Az öregebbje letérdepült, és megcsókolta a kereszten lévő Jézust." Ma már a kereszten lévő Jézus lábának megérintése vált általánossá. A csókolás hagyománya az „öregebbje”, az 1900-as évek elején születettek elfogyatkozásával szűnt meg. „A szentsír eredetileg csupán a keresztből állott. Ezt födték be gyászénekek kíséretében gyolccsal, sőt miseruhával és stólával is. (...) A szentsír, másként Úr koporsója, Csököly katolikusainak ajkán Isten koporsaja, sajátos hazai, illetőleg közép-európai liturgikus fejlemény." 50

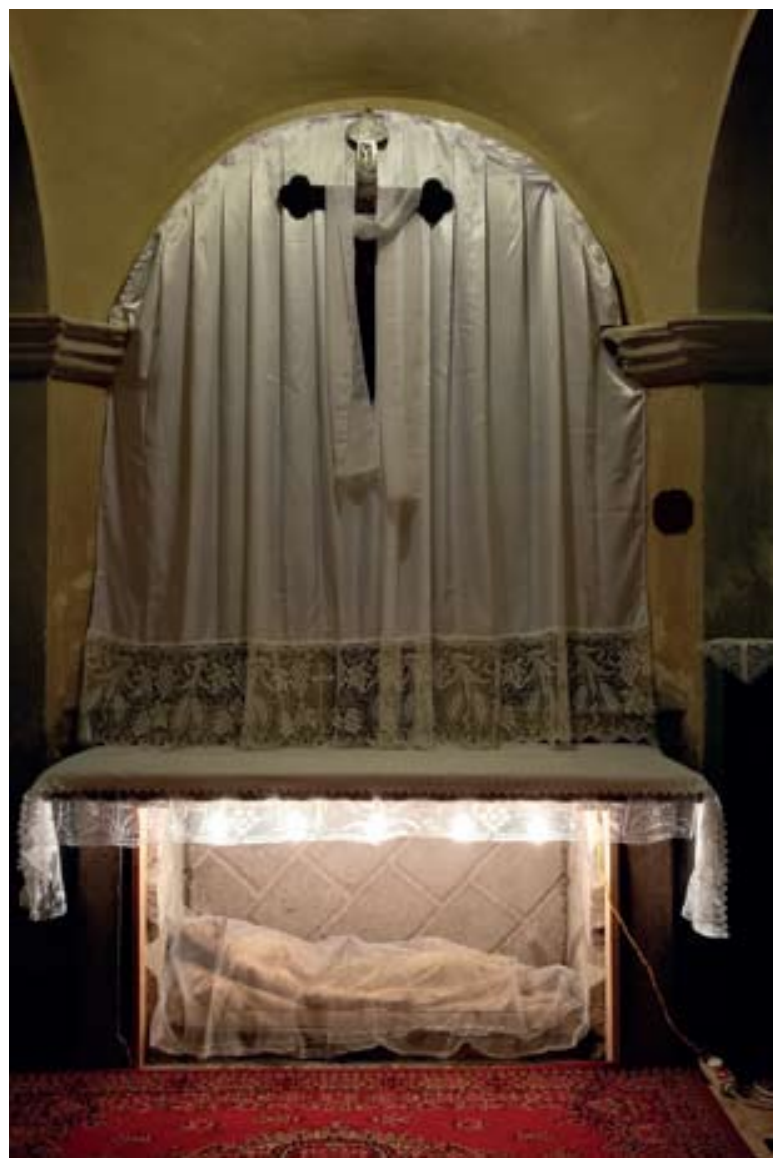

13. ábra. Jézus koporsója szobor Göllében

48 Király L. 2002: 58.

49 hímzett díszpárnát

50 Bálint S. 1989: 259. 


\section{Nagyszombat}

„Hazánkban különös fénnyel szokás nagyszombat délután a föltámadást megünnepelni. Tudjuk, hogy a föltámadási körmenetet csak Közép-Európában ismerik." ${ }^{51}$ „Nagyszombaton véget ér a negyvennapos böjt." 52 „Ekkor a körmenetet a templom körül, a Tanító tartotta Pap nélkül. A tanító megtanulta a kántorizálást (eleve kántortanító végzettségüek voltak). Zászlóval, feszülettel, kimentünk a templomból a kövesútra, megkerültük a templomot. Délután 5 óra felé volt a körmenet. A templomatya vitte a Jézus szobrot megölelte egyik kezével, ahogy tudta. Keresztet, zászlót egyházközségi tag, de mindig férfi vitte. „Feltámadt Jézus e napon.” A Kántort (Tanítót) követte majd 50 gyerek, fölnőttek utánuk.

Feltámadásra rózsaszín mosóruha, vagy piros. Húsvétra mindig új ruhát kaptunk.” "Dicsőség az Istennek, békesség az embereknek!" Ekkor szólaltak meg újra a harangok. Rózsaszín, vagy fehér hortenziát vásárolnak Húsvétkor díszitésként. A demokrácia előtt tojásért cseréltek rózsaszín jácintot."

„A nagyszombat este tartott feltámadási körmenet szakrális célzatai mellett nyilvánvalóan egy archaikus tavaszkezdő szokásnak, a határjárásnak átmentése, az ember közvetlen életterének: otthonának és mezejének, a zsendülö határnak mágikus körbe foglalása, vagyis a gonoszok ártalmának kizárása a közösség világából. Ebben a szemléletben gyökerezik egyébként a búzaszentelő és úrnapja hagyományrendje is.” ${ }^{53}$ „A nép szereti a kollektív ájtatosságokat, szereti a búcsújárást, a vezeklésnek és elégtételnek ezt a nyilvános módját, amely különben a keresztényéletnek, e földi zarándoklásnak is olyan mélységes szimbóluma." 54

\section{Húsvét}

„Az ételek megáldására már Jézus Krisztus is példát adott a csodálatos kenyérszaporítással és az Utolsó Vacsorán." 55

„Régente, ezt már csak hallomásból tudom a favágítóra tették ki a sonkát megszentelés végett.” „Favágító a favágók sajátságos készülete, melyen a fát vágják. Balaton vidékén, az udvarnak azon része, helye, hol a fa áll, hol faragcsálni s fát vágni szokás." 56

„Az 1950-60-as években volt aki biciklivel vitte el Göllébe a sonkát megszenteltetni." Ma Kisgyalánban a misén történik a megszentelése a tormának, sonkának, tojásnak, kalácsnak. „Aki betegség, vagy más súlyos ok miatt nem tudta ételét Ladra elvinni, az hajnalban a favágítóra helyezte, ahol hite szerint Isten angyalai szentelték meg. Ez a hiedelem Boronka, Görgeteg, Kadarkút, Csököly katolikus cselédnépe között is él." ${ }^{57}$
„A fiúknál szokás volt, hogy a hímes tojásokat „kókányolták”, ami a tojások összeütését jelentette, akinek nem törött össze a tojása, az győzött."

„Húsvéti szórakozás volt Kisgyalánban a hímes tojás dobálása $2 \mathrm{Ft}$-ossal. A földre letett tojástól 1 méterre kellett állni, az 1950-es évek elején használt elég nehéz és nagy nikkel 2 Ft-ossal kellett eltalálni a hímes tojást, ha beleállt a pénz, akkor a dobóé lett, ha ötszöri próbálkozás után is sikertelen volt a kísérlet, a tojás a tulajdonosáé maradt 2 Ft."58

\section{Fehérvasárnap}

A lánygyermekek cseperedésekor a 10-12 éves lányok szokása volt férjhez menetelig, a komatál hordása húsvétot követő fehérvasárnap. „Az ifjúsági komálás, mátkálás lényege az életfogytiglani barát kiválasztása s a barátság szertartásos megkötése." 59

„Fonóban természetesen tudták, ismerték a szokást, de érdekesen alakult az „alkalmazása”.(...) „A tálat csipkés kendővel leterítve úgy vitték, mint a kisgyereket. (...) A tanító is tudta ki kinek a komája, „a te komád válaszoljon.” (...) Fonóban, a régi falurészben nem gyakorolták a hagyományt, komatálat csak az új Kossuth utcában hordták." A régi falurészen értendő a Petőfi utca, oka a különböző szokásnak hogy itt a lakosok vérrokonok voltak, míg a Kossuth utcában nem." ${ }^{60}$ A komatál hordás, mint a neve is utal rá, komák közt történik, ami választott úgynevezett mürokonság. „A Zselicben is ismert volt a komatál (mátkatál) küldésének hagyománya. A katolikus cselédség körében az 1920-as évek közepéig élt. A leányok fehérvasárnapon (mátkálló- vagy komázó vasárnapon), de templomba, bálba is fehér vagy fehéres ruhába öltöztek." 61

Kisgyalánban az 1920-as években születettek még választottak komát, és megtartották egész életükben ezt a komaságot. Azonban a II. világháború éveiben már nem választottak komát. A háború nyomasztó hangulata is kihatott a népszerü hagyomány megszünésére, kevésbé volt a vidámságot sugalló komázáshoz kedv, mikor a fronton harcoló apjukért aggódtak a lányok. Mint ahogy lakodalmakat is 1946-tól tartottak újra. „A háború után 1946-ban igen sok házasság köttetett, mivel a háború alatt nem igen volt kedve senkinek házasulni. A Plébános is kifogyott már a magasztos beszédekböl a sokadik ceremónia után, s így fakadt ki: „Hát nektek már mit is mondjak!'ø2

Több hagyománnyal kapcsolatban hangzott el, hogy a „háború után már nem volt szokás.” A változó világkép, a rendszerváltás mind hatással voltak a hagyományok átalakulására. „Ti is a templomban tanultátok a hittant, nem engedték be az iskolába." hangzott el az 1930-ban született részéről az 1968-as számára.

\footnotetext{
51 Bálint S1937: 87

52 Tátrai Zs. -Karácsony Molnár E: 1997: 96.

53 Bálint S. 1937: 88

54 Bálint S. 1937:11. 12

55 Tátrai Zs. -Karácsony Molnár E: 1997: 97

56 Favágító | A magyar nyelv szótára - Czuczor-Fogarasi | Kézikönyvtár https://www.arcanum.hu/hu/online-kiadvanyok/Lexikonok-a.../favagito-5D77B

57 Bálint S. 1989: 297
}

\footnotetext{
58 Lanszkiné Széles G. 2007: 172.

59 Lévainé Gábor J. 1963: 230. 231

60 Lanszkiné Széles G. 2013/B: 272

61 Eperjessy E. 2006: 226. 242.

62 Lanszkiné Széles G. 2007: 196
} 


\section{HÁROM KAPOS MENTI KÖZSÉG NÉPÉNEK RÉSZVÉTELE A KATOLIKUS EGYHÁZ HIVATALOS JELES NAPI ÜNNEPEIN, AZ 1930-AS ÉVEKTŐL \\ NAPJAINKIG}

\section{Búzaszentelés}

Márk evangélista ünnepe. E nap jellegzetes szokása a búzaszentelés, amelyet általában Márk napjának délelőttjén, ritkábban az ünnep utáni vasárnap tartották.

„Irgalmasság vasárnapja, búzaszentelési körmenet április. 24. Szent Márk napján. Szárba szökött a búza. Üsztörgye alá beszúrták a búzaszálat, vagy a léc és a cserép közé. A mise után Ö’tözetesen (ahogy a misén voltak, azon módon) kimentünk a határba, a legközelebbi búzatáblába. „Hallgasd meg Uram könyörgésemet! Engedj meg minekünk, jó termékeny vetéseket." A gyalániak nem mentek vissza a búzaszentelés után hálaadásra Göllébe a templomba, Gyalánban nem volt körmenet. Ma már nincs körmenet, a sekrestyés viszi ki az oltárra a megszentelt búzaszálakat, amiből visznek haza a hívek." A búzatáblák mérete sem akkora, mint a táblásítás előtt, nem a kisparcellás módon művelik a földet. Ha elindulnának a körmenetre, valószínüleg nagy volna az esély arra, hogy a régi jól járható dűlőutat sem lelik meg hozzá, vagy ha nem szántották be, akkor nincs gyalogosan a közelben aránylag hamar elérhető búzatábla. „2018-ban Kisgyalánban elfelejtettek búzát vinni a templomba, így a Domit szalajtották el a legközelebbi búzatáblába búzáért."

Fonóban is: „Az egyházi ünnepekre mindenki szívesen emlékezett vissza, kiemelve a közösen végzett elökészületeket, a közös határszentelést. „Szent Márk után következő vasárnap, az 1950-as évekig, kivonultak zászlókkal, keresztekkel a Gecseny felé búzát szentelni. Itt a határban a pap a négy világtáj felé fordulva négy evangéliumból énekelt áldást kérve a határra. A megszedett búzacsokrot megáldotta a pap, a templomban elosztották a búzaszálakat."63 „A búzaszentelési körmenetet az ötvenes évek elején betiltották, azt követően vagy a templom falain belül végezték el a búzaszentelést, vagy kénytelenek voltak még arról is lemondani." ${ }^{4}$ Jelen években a templomban történik a búzaszentelés Fonóban is." 65

\section{Keresztjáró napok}

Áldozócsütörtök előtti hétfő, kedd, szerda, testi-lelki javakért könyörgő, imádságos napok. ${ }^{66}$ „A keresztjáró napokon, Fonóban, fagyosszentek reggelén közösen elmentek a négy kereszthez. Az 1940-es évek végéig kerekedtek fel, főként asszonyok a keresztekhez. Az elsőnek felkeresett kereszt a Kis-erdőnél, a Fonai Márton házához közel lévő kereszt, ezt Kis Fonai Sándor öreganyja állíttatta férjéért, aki eltünt a háborúban. A következő állomás a Keczeli kereszt a Farkas-agárcásnál, majd ezt követte a Várnál lévő, a kultúrháznál, illetve a volt gépudvar mellett, ez a malom felé vezető úton található kereszt volt a határ a falu és a kegyes tanítórend birtoka között, $A$ keresztjárás hétköznapra esett. A kereszteknél imádkoztak, énekeltek. Csak a szorgalmasabbjai mentek el rá, 10-12 személy, akinek nem volt annyi állata, vagy otthon volt az anyósa, aki etetett helyette. Vagy aki nagyon akart, rá

63 Cséplő József szíves közlése.

64 Bognár S. 2001: 04. 29

65 Lanszkiné Széles G. 20013/A:

66 keresztjáró napok - Magyar Katolikus Lexikon. lexikon.katolikus.hu tudott készülni, korábban ellátta az állatokat. Aki egyes asszony volt, anyóstól külön háztartásban, több teendője akadt reggelenként, nem volt segítsége. ${ }^{\prime 67} \mathrm{Az}$ ünnep és munka nem elválasztható egymástól, az egyik kedvéért áldozni kell a másikért."68

\section{Áldozócsütörtök}

„Jézus Krisztus mennybemenetelének ünnepe Húsvét után 40 nappal, ekkor volt az elsőáldozás. Ami minden esetben csütörtökön tehát a napján volt megünnepelve. Megtörtént az 1930-as évek második felében, hogy a Nagyberki búcsúval egybeesett." Aminek az lett a következménye, hogy az éppen akkor Göllében elsőáldozó kisgyaláni Széles Rózsa, akinek nagyszülei Nagyberkiben laktak, azért nem kerülhetett rá a Göllében az ez alkalommal készült csoportképre, mert indulni kellett a Búcsúba. Amit szintén a napján tartottak, lévén sátorosünnep, megengedhetetlen volt, hogy a közvetlen családtagok ne vegyenek részt rajta. Azonban a fényképet illetően, némi vigaszt nyújthatott, hogy amikor Grábner fényképész hozta az elkészült fotókat, őt külön lefényképezte, amire valószínűleg nem kerülhetett volna sor ha a csoportképre rákerül. A somogyi kis falvak akkori egymás közötti szoros kapcsolatát bizonyítja, hogy tulajdonképpen ez a búcsú Mosdós egyházközség búcsúja volt, Nagyberkinek ekkor még, nem lévén saját temploma. Ezért a szomszéd községgel együtt tartotta a búcsúját. A zenét a szalacskai cigányok szolgáltatták. „Húzzátok szalacskai ...,.. Két, három cigány húzta, a Mama leintette őket." Az elsőáldozásokat az 1950-es évekig Göllében tartották, melyröl egy 1942-es fotó is tanúskodik (14. ábra). $\mathrm{Az}$ áldozási csoportképen látható Parragi Béla körül összegyült nagyszámú gyereksereg. Gölle, Kisgyalán, Fonó, Imámpuszta nyolc év körüli gyerekei. A következő 15. ábrán a Nagyberki templom szentelése látható. „Akkoron még, nem kívántak uniformizálódni. Nagyberkiben, az 1946-os templomszenteléskor készült fénykép a falvak közötti viseletbeli különbségröl tanúskodik. A templom sarkánál a hosszú ruhás pulaiak, középen a térd alá érő bő szoknyás gyalániak, kissé távolabb mögöttük az attalaiak viselete látható." (...) Ma már távo-

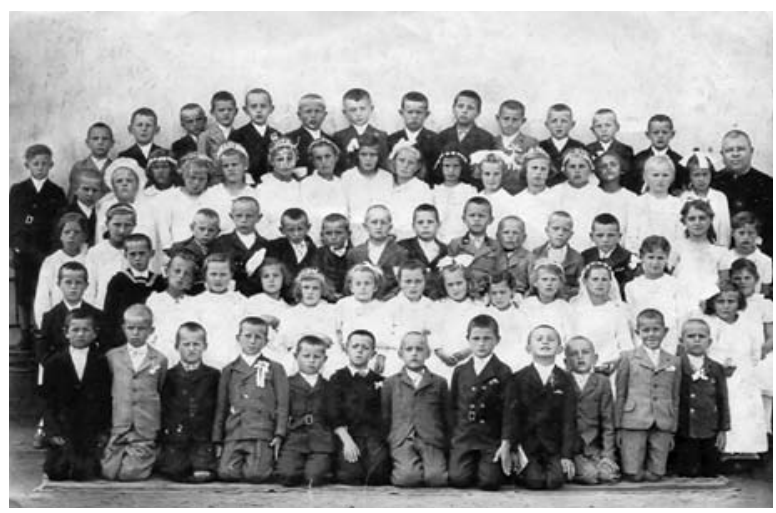

14. ábra. Elsőáldozás Göllében 1942

67 Pál Elemérné (Zóka Margit) szíves közlése

68 Lanszkiné Széles G. 2013/A: 159. 


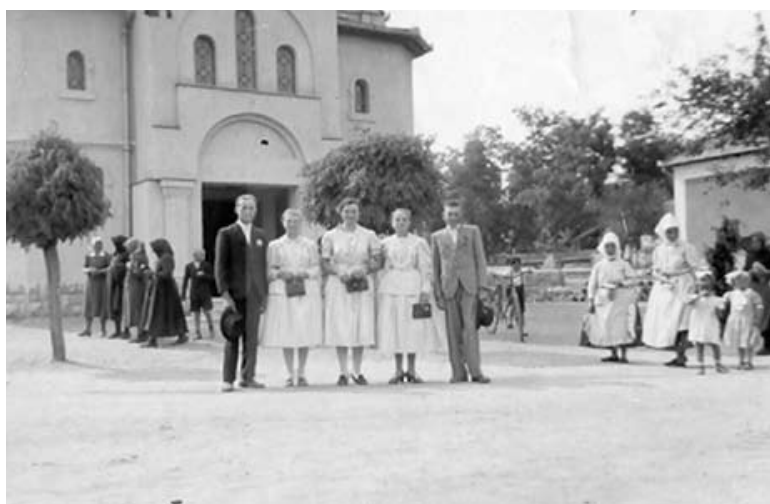

15. ábra. Templomszentelés Nagyberkiben

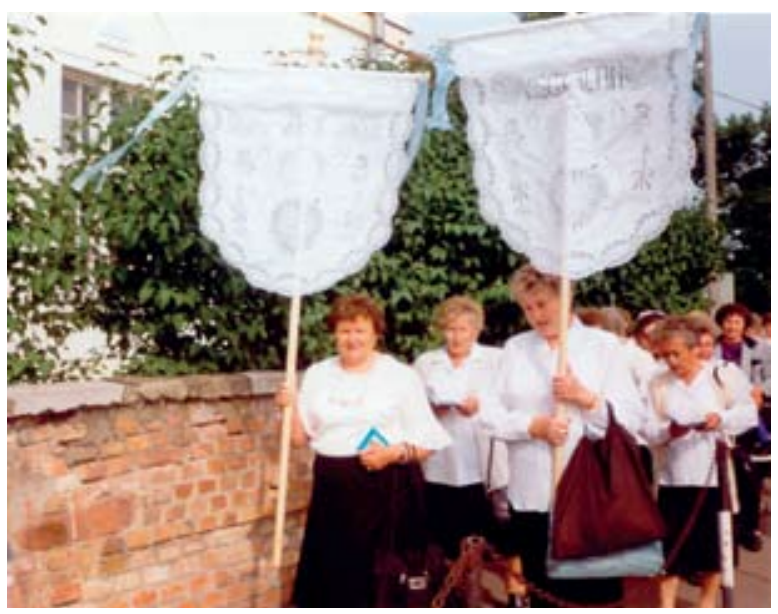

16. ábra. Templomszentelés Mezőkövesd

labbi helyekre is szerveznek búcsújáró kiránduló utakat. 2000-ben Mezőkövesden az új „Kistemplom” szentelésén is több gyaláni is részt vett, ahogy ezt fénykép is tanúsítja (16. ábra). A képen Major Károlyné által készített zászlót viszik a Kisgyalániak." 69

\section{Pünkösd}

„Két napos ünnep, senki nem dolgozott ilyenkor. (A lovak ekkor kaphatták, az úgynevezett pünkösdi betegséget, mert nem mozogtak, nem dolgoztak.) A pap pirosba teszi a misét. Szentlélek eljövetelének ünnepe. "Szentlélek Úristen, áraszd reánk ..."

„A kétrészes viselethez felül tartozott a blúz, amely többnyire galléros selyemblúz volt. Ez színében egyházi ünnep szerint is változott. Pünkösdkor piros, fehérvasárnapkor fehér blúz illett."70

„Mindenki nagyon szépen felöltözött, Sinkovics Ferkó bácsi mire a rossz ruhából felöltözött, csak a mise derekára ért oda Göllébe. Nem volt ám 5-6 férfiruha, mint most! Abba' temették el amit vasárnaponként rávett magára!"

\section{Úrnapja}

„Pünkösd után Szentháromság vasárnapja következik, Somogyban több 18. század végi templomunkat szentelték tiszteletére, ezen a napon megyénkben sokfelé van búcsú (pl. Büssü, Balatonlelle stb.). A következő csütörtökön van Úrnapja, s mivel ez a katolikusok egyik legnagyobb ünnepe, régen munkaszünet és munkatilalom kapcsolódott hozzá (jelenleg a következő vasárnap tartják meg. Úrnapján mindenütt körmenet volt, ahol a pap baldachin alatt vitte az Oltáriszentséget, s ezen a szertartáson minden hívő részt vett, még a pásztorok is bejöttek a faluba. Az úrnapi körmenet útvonala mentén négy szabadtéri oltárt álítanak fel, az egyes sátrak készítői vetélkednek egymással, hogy kié a legszebb."71 Göllében a 2000-es években készültek fényképek az Úrnapi körmenetről (17-28. ábra).

Fekete István így ír Úrnapja előkészületeiröl, és ünnepléséröl: „A két ember között békesség van, ünnepvárás, és akármire gondoltak jól van az úgy nagyon. A házak eleje el van már seperve... Vince már leverte a sátorfákat. .. Rakják, igazgatják, simogatják az ünnepi sátrat. A zöld gally körülveszi lassan az utca egy kis darabját, s homályos barlangja előtt már elkülönülve jár a hétköznapi élet. Magda körülsepri még a sátrat, Anna a lehullott gallyakat visszadobálja a kocsiba, s amikor egyedül maradnak, sötét már a sátor belseje, és a fonnyadó leveleket, de azok aléltan őrzik a fehér asztalt s a két szál gyertyát, és halk sodródásukban, szomorú zizegésükben mintha suttogás bujkálna. A gyertyatartók csillognak, mert üvegböl vannak. Belül valami fényes port fújt rájuk az üvegesmester, amitöl ezüstös fényben csillognak. (...) Az üvegből készült ezüst gyertyatartók kevélyen állnak az árnyékban, és csillognak, és unottan nézik a poros utcát, a kéziszőttes terítőt, a halvány nyárfagallyakat. (...) A templomajtó nyitva, az oltár a tömjén lágy ködében úszik, a zászlókat kiemelték már tartóikból, s most indulásra készen rezdülnek meg, mintha kifelé vágynának a napsütésben. A kóruson fogják már a harangköteleket, s a harangozás élvezettel vegyes tisztségét. (...) Az orgona már elhallgatott, az iskolás gyerekek már indulnak kifelé, megmozdult a lányok színes karéja, felállnak a fekete padsorok, felzendül újra az ének, s a zászlók meghajolnak a templomajtóban, selymük lobogására rászáll a nap, s a toronyba ujjongva zendül meg a harangszó. (...) Ekkor gyúitja meg Petiné a gyertyákat. Az ő sátruk ugyan az utolsó, de ma takarékoskodni nem lehet, s a gyertyák sápadt fénye tünődve lobog a terítő felett. .... S a lángok láttak! Látták a gyerekek együgyü botorkálását, tiszta szemükbe a csodálkozást, látták a léptek keménységét vagy elesettségét, a fiatalság lüktető szívét s az öregek ráncos arcát, látták az elmúlt napokat, a panaszt, a reményt, a szerelmet, a bánatot, ruhákat és imakönyveket, zászlókat és pántlikákat. És látták a vágyat az ima betüibe a hit szárnyába kapaszkodva, és tudták, hogy az emberek emberi kicsinyességéért nem haragszik az, Aki semmiért sem haragszik. (...) az öreg Banádi esőt kér, mert a szénáját már behordta, Szabadi Gábor szép időt, mert a szénája még kint van. (...) Mindent láttak a kis lángok."72

$\begin{array}{ll}71 & \text { Király L. 2002: } 94 . \\ 72 & \text { Fekete I. 1972::77. } 80 .\end{array}$
69 Lanszkiné Széles G. 2007: 157. 173. 174.

70 Fehér Károlyné szíves közlése. 

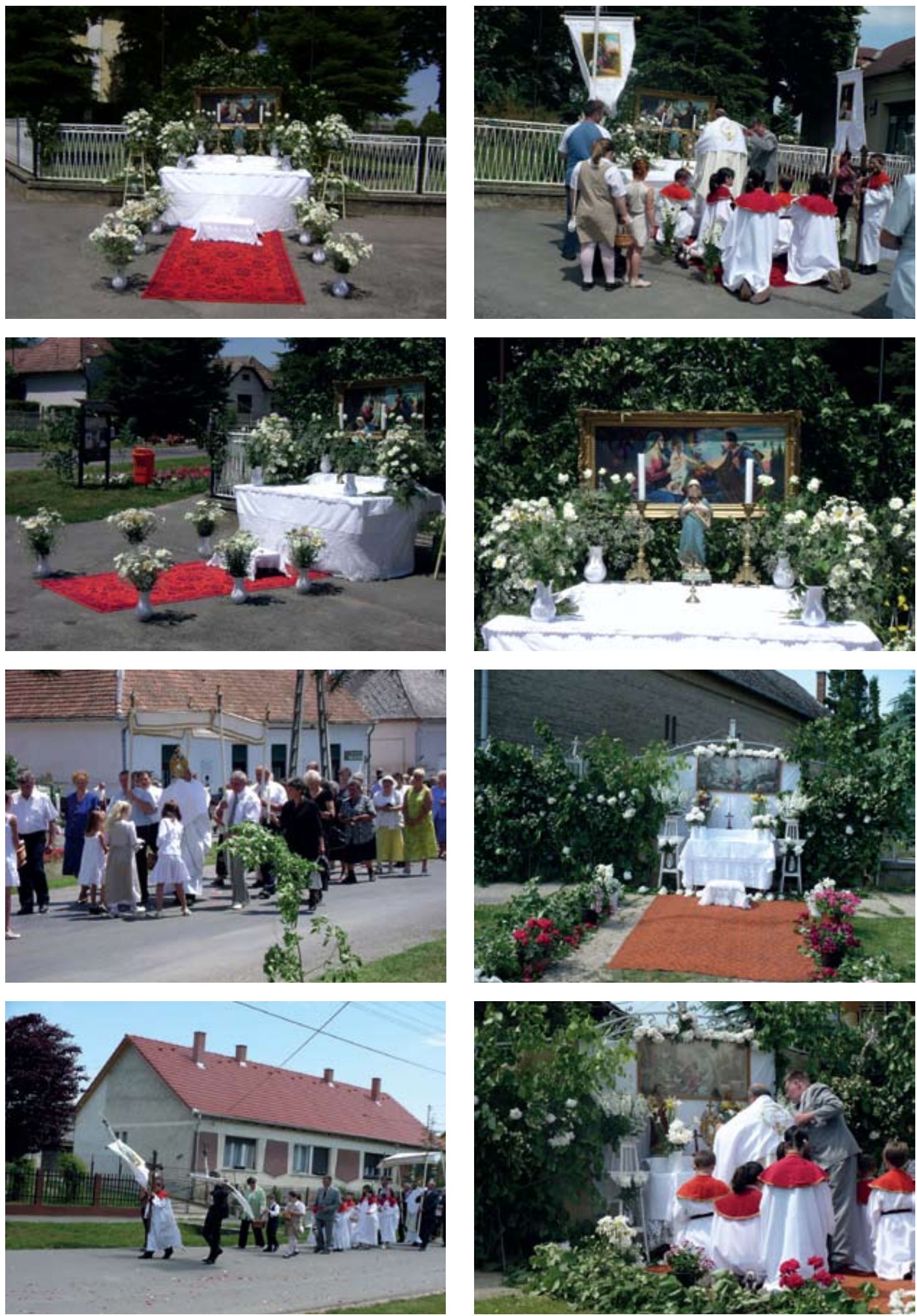

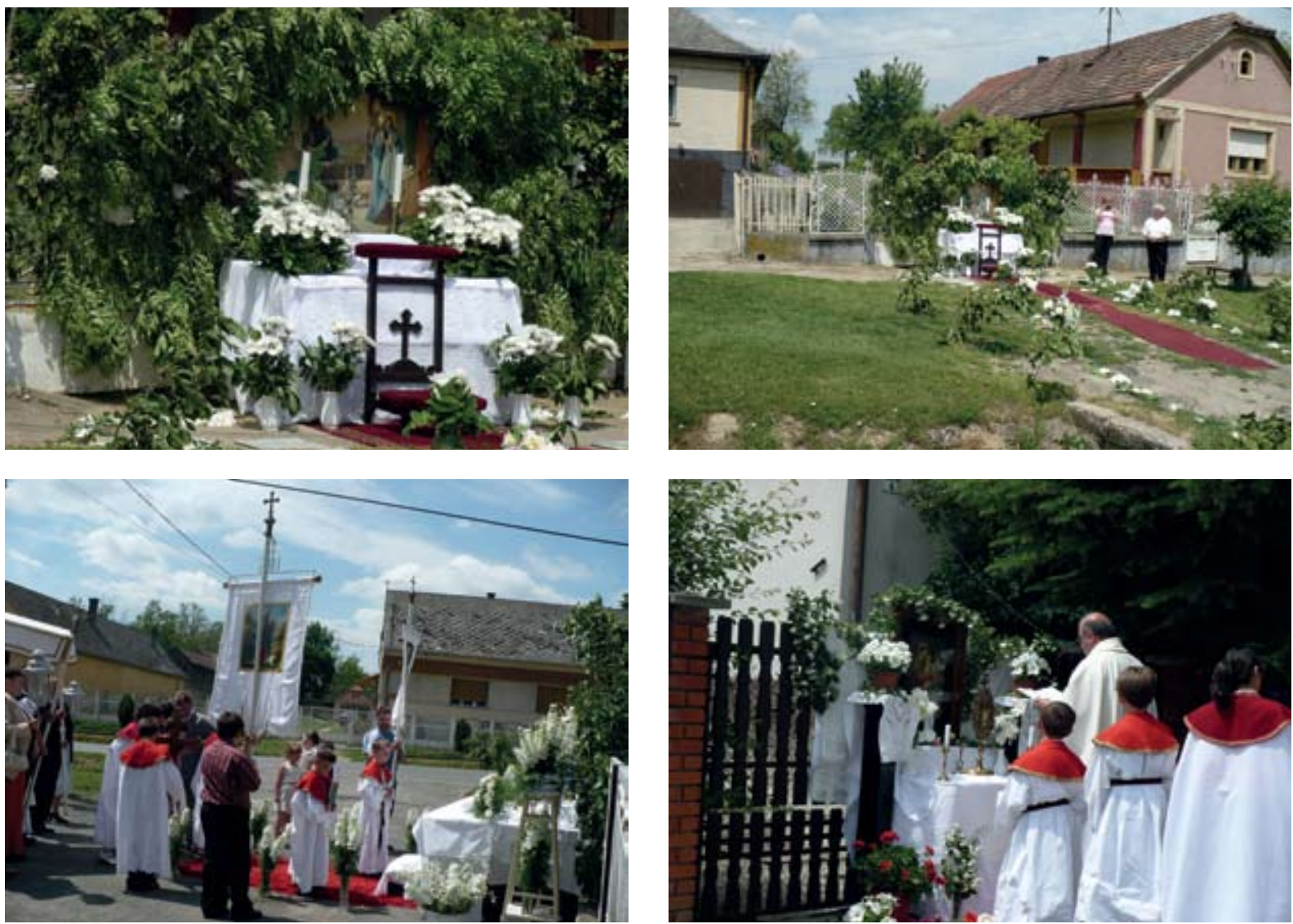

17-28. ábra. Úrnapja Gölle 2000-es évek

„Pünkösd után tíz nappal, Göllében nagy mise az oltáriszentséget kivitték a zombella ${ }^{73}$ alá, ezt négy ember vitte, kiknek egyszerre kellett lépniük. A négy sátor a négy égtáj felé nézett, hársfalevéllel volt borítva kívülröl, belülről fehér gyolcslepedő. A pap mind a négy sátorba bement, de nem beszélt, mégis jobban elmentek mint a misére. Hosszi menet volt. Esküdték és az Annus között (az út két oldalán az első két ház, ahogy beérünk Göllébe), a díszkapu itt a kövesút felett ivelt át, „Isten hozott !" fölirattal. Éppen akkor nyíló kerti virágokkal díszítették a díszkaput. Minden négy évben, gyütt a püspök." A két körmeneti zászló fehér selyemdamaszt, egyik oldalán olajfestésű Madonna, valamint Jézus található.

A fonói visszaemlékezés így hangzott: „Az úrnapi oltár készítése a mozgó ünnepek közé tartozik. Húsvétot követően hat hétre tartják. A körmeneten négy oltárt állítanak, amelyet a pappal és az oltáriszentséggel végigjárnak a hívek. Az úrnapi körmenetnek saját liturgiája van. A stációknál evangéliumot olvasnak, és a pap az égtájak felé áldást oszt. „Az emberek az áldás idejére letérdeltek, csak úgy harsogott, úgy énekelt az egész falu. A négy égtáj irányába négy sátrat készítettek az utcán, a négy evangéliumot olvasták fel bennük. Az 1950-es évektöl, amikor a szoritás begyütt, attól kezdve a templomkertben épitették fel a sátrakat. Az 1970-es években maradt el az úrnapi sátor épitése. Lécböl összerakott vázra le-

73 Az umbrella esernyő szóból eredeztetve. veles ágakat, tölgyfaleveleket, virágokat helyeztünk. Két kocsi fiatalabb ágat is hoztak az erdőböl. A megszentelt virágból mindenki kapott. Nyolc vázába fehér szegfüt raktunk. Szépen el volt látva. A sátor belső részébe szent képeket akasztottunk, asztalt állitottunk. Az asztalra vastag szentírásos könyvek, köröszt, gyertyatartó, vázába virágok kerültek, a földet letakartuk szönyeggel. Minden család azt adott a sátor berendezéséhez, amiből neki volt a legszebb." ${ }^{\prime 4}$

Kisgyalánból az ünnep fényét emelendő, Csima Lajosné (Vörös Erzsébet) menyasszonyi ruháját vitték át Márton Erzsébet számára az 1950-es években Göllébe, mivel az angyalnak öltözött lányoknak fehér ruhát kellett viselniük. A két község között manapság is müködik ez a jellegü kapcsolat. ${ }^{75}$ „Elöl rózsalevél hintő kislányok haladtak, kiskosárból rózsaszirmot szórtak az oltáriszentség elött. A résztvevők nem népviseletet, hanem fehér selyemblúzot öltöttek magukra. A legfrissebb új menyecske állt elöl. Négy egyházközségi tag vitte a zombellát, amelynek fehér volt a teteje, körü' sallangós, gyaláni egyházközségi tag is vihette”.

Meg volt, hogy ki előtt áll a sátor. Oláh Lászlóné (Kovács Irénke) családja 1967-től kezdve, 48 éven át vitte a sátordíszítést. Esküdték előtt mintegy 40 évig, Deresék, valamint a Szalai család előtt körülbelül 10 évig volt lomb-

74 Pál Elemérné (Zóka Margit) szíves közlése.

75 A kisgyaláni kalocsai hímzésű miseruhát bérmálás alkalmából viselte a Püspök Úr az 1980-as években. 


\section{HÁROM KAPOS MENTI KÖZSÉG NÉPÉNEK RÉSZVÉTELE A KATOLIKUS EGYHÁZ HIVATALOS JELES NAPI ÜNNEPEIN, AZ 1930-AS ÉVEKTŐL \\ NAPJAINKIG}

sátor. A vasúton alu' nem építettek sátrat. Jelen években, a templom udvarában az úgynevezett Bástyán a templomdombon készül el az Úrnapi sátor. A fényképek alapján jól látható, hogy az évek elörehalad tával kisebbek lettek a sátrak, és 2018-ben már nem is építettek az oltár fölé sátrat (29. ábra), míg 1939-ben még be lehetett állni a sátor alá (30. ábra).

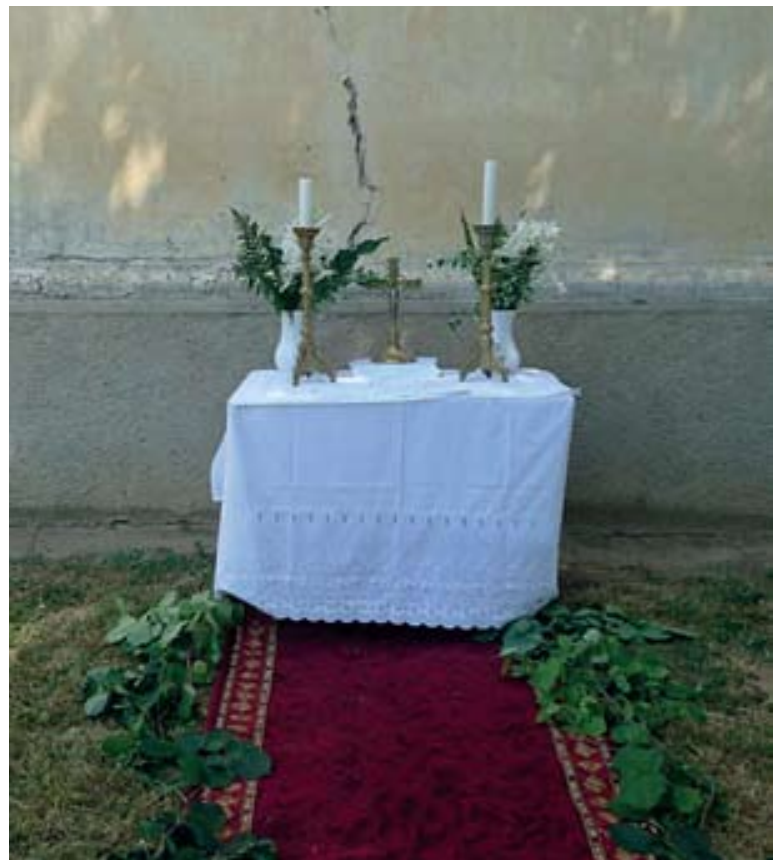

29. ábra. A templom előtt a Bástyánál Úrnapi oltár 2018-ban

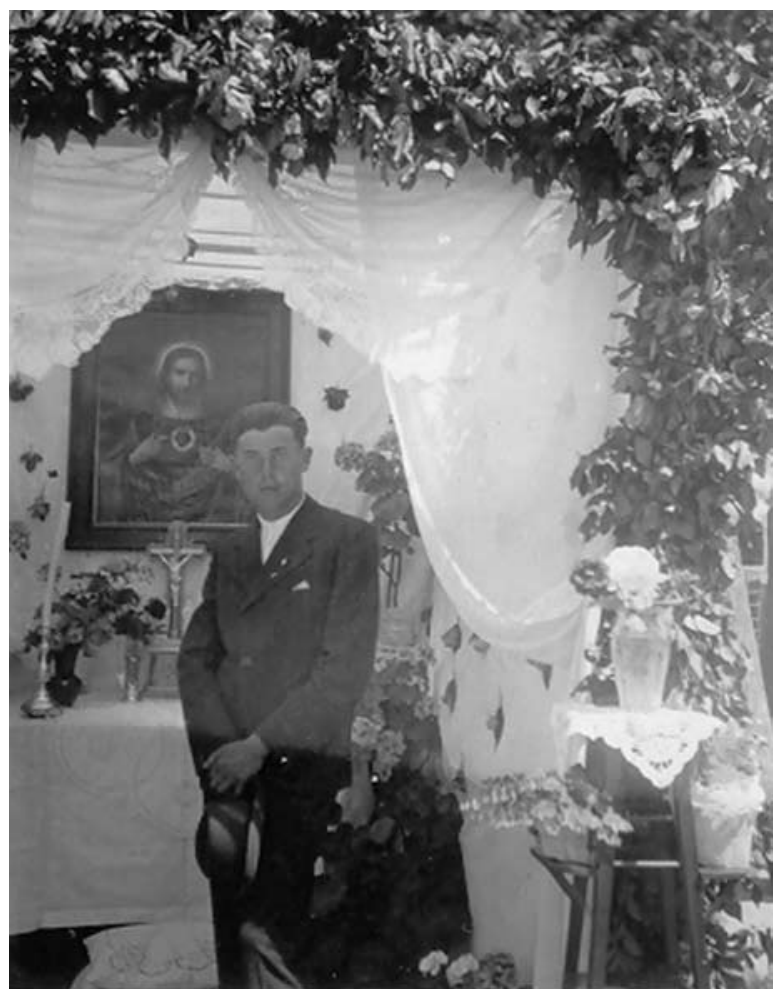

30. ábra. Úrnapi sátor 1939-ből

\section{Július 2, Sarlós Boldogasszony napja}

Többszörösen elöfordul naptárunkban a Boldogaszszony napja. A régi magyar nyelvben Szűz Mária egyik neve Boldogasszony volt. Ezek az ünnepek fontos munkák megkezdésének időpontjait jelezték, amire az elnevezések is utalnak: Gyümölcsoltó Boldogasszony, Sarlós Boldogasszony. ${ }^{76}$

„Az ünnepet népünk is fölkarolta, bizonyára azért, hogy az aratás idejére esik. Mária a Megváltót hordozza méhében, aki áldást hoz az emberekre és munkájukra. Innen a magyar neve is: Sarlós Boldogasszony."77

„Kisgyalán fogadott ünnepe Sarlós Boldogasszony, nagy ünnep. Lányok kapták a selyemblúzot, azért kapták mert átgyütt (Gölléből) a pap. A pusztáról is gyüttek be a misére. Mindenesetben napján tartott ünnep, mind a mai napig." Mint már eddig is kiderült az új ruha fontossága, fokozottan fontos volt abban az esetben, ha a falu fogadott ünnepéről volt szó., és ha a plébános a saját falunkban tartotta misét.

„Július 2.-a annak tiszteletére vált a megemlékezés napjává, hogy a villám agyon vágta a csordásokat, valamint a teheneket, és hatalmas szélvihar kerekedett." Nem emlékszik senki az évszámra, bár Bóna László visszaemlékezése szerint édesapja, aki 1866-ban született ekkor 9 éves gyerek volt, amikor ez történt. Az 1874-es anyakönyv tanúsága szerint 17 éves csordás János, Sebők Károly fia halt meg ekkor. ${ }^{78}$

\section{Augusztus 6, Urunk színeváltozása}

„Augusztus 6. 1800-as években vasárnap tartott ünnep. Máig is tartott ünnep. Fekete betüs ünnep, Ilyenkor csavartak egy kis újbort. A demokrácia nagyot változtatott a valláson.” "URUNK SZÍNEVÁLTOZÁSA napján a szőlőt áldja meg az Egyház (...) Kiskunfélegyházán az a hiedelem, hogy ezen a napon kezd a szőlő tarkulni." ${ }^{" 79}$

\section{Augusztus 15, Nagyasszony napja}

„Szüz Mária mennybemenetelének ünnepe. Teste nem lett a földé, hanem megdicsőült." ${ }^{80}$

\section{Szeptember 8, Kisasszony napja}

„Szeptember 8. Szűz Mária születésnapja, sok búcsújáró helyünknek legfőbb ünnepe.""1

„Világjárásra, távoli utazásra nem igen nyílott mód a szűkre szabott anyagi javak mellett. Az 1970-es évekig a búcsúba járás töltötte be ezt a szerepet. „Ez volt a kirándulás, más lehetőség nem volt." De természetesen a kirándulás csak a másodlagos szempont, a vallás szerepe az első.

A leglátogatottabb búcsújáró hely Andocs volt, ahová is mind a mai napig járnak búcsúba.

Kisasszonykor, valamint Nagyasszonykor történtek a „processziók”. Ezek az időpontok az időjárást tekintve is kedvezőek voltak. 20. század elejéig, közepéig gya-

76 Bihari A., Pócs É. 1985:125.

77 Bálint S. 1937:116

78 Lanszkiné Széles G. 2007: 172

79 Bálint S. 1937:119.

80 Bálint S. 1937: 120

81 Bálint S.1937: 121 
log, később Igalig lovaskocsival, majd onnan az igali erdőn keresztül gyalog mentek a búcsúba.

Átlagosan 30-40 fő vágott neki az útnak. A búcsút megelőző napon indultak és egy Andocshoz közeli szénapajtában háltak meg. Ponyvát, pokrócot adtak a helyiek. A búcsúi ruhát a bugyorkötőben vitték. Amely 1 négyzetméter kékfestő anyagból készült. Mivel az anyagok általában $80 \mathrm{~cm}$ szélesek, ezért $20 \mathrm{~cm}$-rel meg kellett toldani az anyagot, melyet alul egy boggal, és felül keresztben másik csomóval átkötötték.

A búcsújáró menet elején haladó vitte a keresztet. Ez a kereszt ma már új, a régit „elette a szú”. Az új keresztre a régi korpuszt helyezték tiszteletből. Menet közben ide illő vallásos énekeket énekeltek. Több faluból mentek egyidőben, természetesen találkoztak útközben. „Így egyszer a gölleiekkel találkozván megmosolyogtatta a gyalániakat, mikor hallották, hogy a "Csordapásztort" (karácsonyi ének), énekelik, amit ugye nem búcsújáráskor illik előadni, de már kifogytak a búcsújáró dalokból."

Búcsújárásra már az öt éves gyerek is ment. Aki először ment Andocsra, azt az andocsi templom melletti szent kútnál megmosdatták, ezt hívták „mosdatásnak”. A mosdatást végző asszonyt attól kezdve körösztanyjának kellett szólítania a gyereknek. Ezért „már eleve valami komaságba keveredett mosdatta” a gyereket. Például testvére bérmakörösztanyja, nehogy az egész falu komasági viszonyba keveredjen a kört szükíteni kellett.

Megérkezve, másnap reggel átöltözve mentek a misére, ahol következett a gyónás, majd az áldozás. Utána a búcsúban bábolvasót kellett venni az otthon maradt gyereknek, ajándék nélkül ugyanis nem lehetett hazajönni. Ezt, ahogy az 1920-as években ugyanúgy most is elvárják a gyerekek. Van, ami száz év múltával sem változik. Élelmet útközben nem vettek, hazafelé a „Bonnya-kútnál” ebédeltek meg a magukkal vitt kolbászból, szalonnából, pecsenyehúsból, kalácsból.

Otthon a „várók” az érkezők számára az érkezésükkor megcsendítették a harangot és énekkel várták őket a templomban. A búcsújárók többsége a falusiak közül került ki, de a pusztaiak közül is velük tartottak páran.

A 1960-as évektől még buszt fogadtak ezekre a napokra, úgy utaztak. A 1970-es évektől kezdve saját autóval, ki-ki elviszi szomszédját, rokonát, komasszonyát."82

\section{Szeptember 14, Szentkereszt felmagasztalása}

Szeptember 14. Gyaláni Búcsú Mária neve napja. „Búcsúkor a lányok kávészínü, fekete vagy más színü bársonyszoknyát vettek, elmentek a masina (cséplögép) mellé, és megkeresték rá a pénzt. Na persze nem minden évben volt új szoknya. Búcsúkor minden háznak volt vidéki vendége. Sorakoztak az udvarokban a parasztkocsik, és az elölük kifogott lovak, a lovak nem tértek be az istállóba. Ma a hidakon az autók sorakoznak."

82 Lanszkiné Széles G. 2007: 171. 172.

\section{Október 20, Szent Vendel napja}

„Október 20.- a misét a temetőben tartják, mert itt van a kápolna Göllében. Sokan elmennek Gyalánból is."

„Az állattartók védőszentjére emlékeztek a göllei temetőben épített kápolnánál. 1754-ben a Dél-Dunántúlon marhavész-járvány pusztított, mely a göllei gazdákat sem kímélte. Öseink ekkor fogadták meg, hogy kápolnát építenek, és ott tartják meg a szentmisét, kérve a szentet, hogy kímélje meg őket e nagy csapástól. Szalai Jeremiás prépost plébános minden évben Szent Vendel tisztelete Göllében vendég papot kér fel a szentmise megtartására. (...) Elődeink először egy fogadalmi keresztet emeltek, még 1760-ban, majd 1786-ban elkészült a kápolna is, mely végleges formáját 1887-ben nyerte el. (...) Fekete István író vallásosságáról is megemlékezett. Mint az köztudott a község nagy szülöttje, aki a családi nevelés mellett a volt göllei parasztembereknek is köszönhette hitét. Ahogy a Ballagó idő címü életrajzi regényében is írja: „Itt kerületem kapcsolatba a természettel, a hittel és az egyszerü, de értékes parasztemberekkel"83

„A kultusz elevenségét jelzi, hogy Göllében a templom melletti Hősök terén 2011-ben felállították Szent Vendel faszobrát. Alkotója subában, oldalán tarisznyával, kezében juhászkampóval, lábánál báránnyal formázta meg. Szépen fogalmazott felirata: SZENT VENDEL PÁSZTOR REMETE-APÁT 554-617 (...) Csodái föleg a járványos betegségek áldozatain mutatkoztak, illetve azok tapasztalták jóságos közbenjárását, akik állataik bajaiban hívták segítségül. (...) Fogadott ünnepként tisztelik október 20-án Szent Vendel napját. A szobrot a hálás utókor nevében közadományból állíttatta Gölle Község Önkormányzata 2011. 10. 20. Faragta vitéz Varga Károly Szentgáloskér (31. ábra)." ${ }^{84}$ A templom fő homlokzatát is Szent Vendelről mintázott ólomüvegkép díszíti (32. ábra).

\section{Mindenszentek}

„November 1. Sötétíteni kellett háború alatt, nem lehetett gyertyát égetni a temetőben tiltották, az ellenséges repülőgépek miatt."

Szentségimádás: „Ilyenkor a rabokért is mondanak misét."

\section{Márton napja}

„November 11. Somogy megyében a következő katolikus templomok viselik Szent Márton nevét: Csököly, Fonó, Fonyód, Polány (kápolna), Táska, Vörs. A templombúcsúra általában két héttel korábban meghívják a vendégeket. (...) Márton napján ismert hagyomány a hízott lúd fogyasztása, ez a szent legendájával függ össze." 85

\section{December 13, Luca napja}

„Nem volt szabad varrni! Előtte való nap varrtam. Nem tojtak a tikok, mert a lány varrt! Imádkoztam. V'ót

83 Fekete István Múzeum honlapja. www.feketeistvanmuzeum.hu/ hirek/szvendel2013.htm Bodó Imre

84 Lukács L. 2014: 243. 244

85 Király I. 2002:126. 127. 
NAPJAINKIG
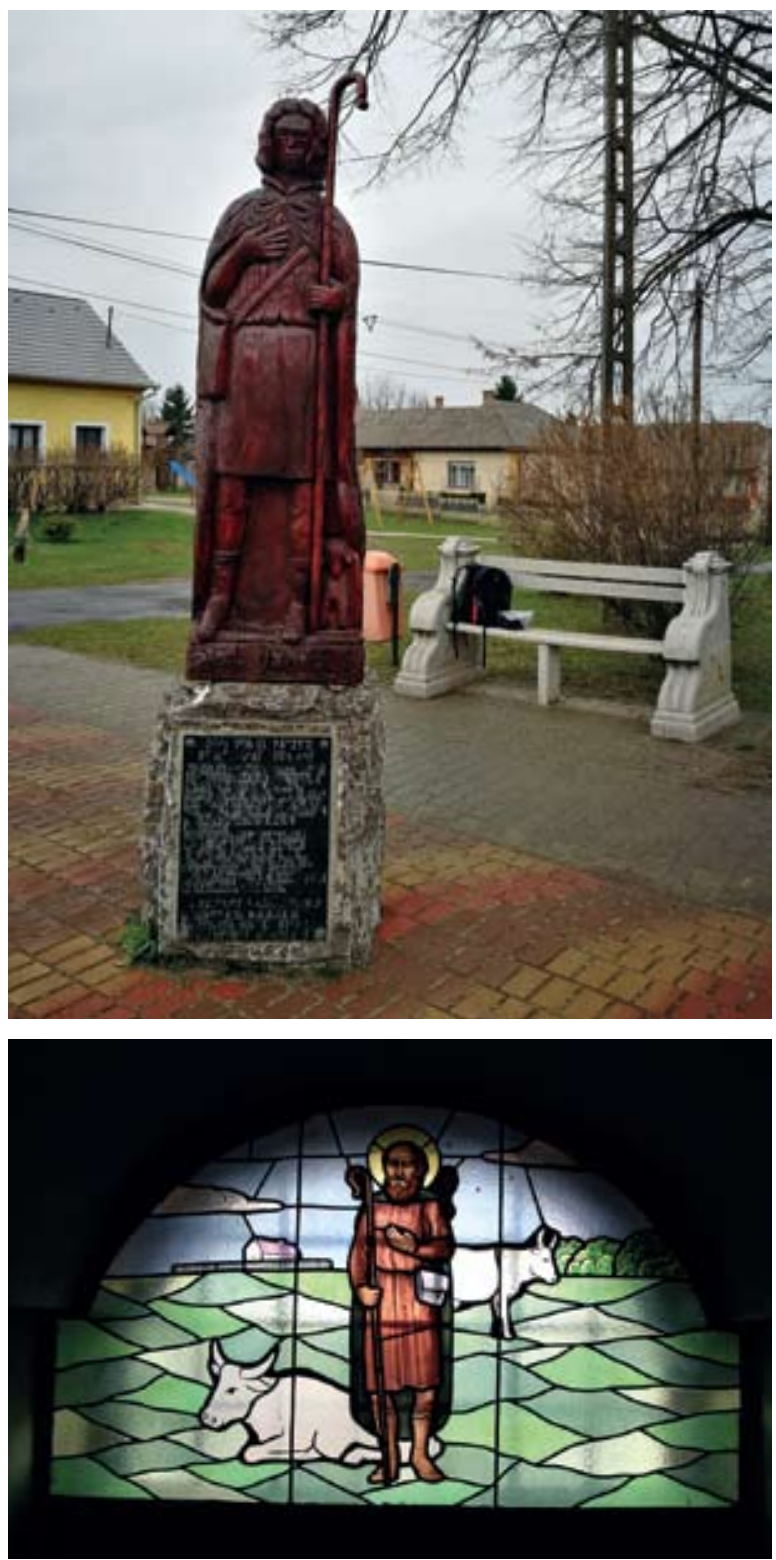

31-32. ábra. Szent Vendel

öröm megmonyasodott ${ }^{86}$ a tik. Monyas tikokat ha letojt akkor engedtük ki mert nem volt kerítés." Mindez a viszszaemlékezés már mosolyogva történt, látszott Nagynéném tekintetén, és a kézlegyintése is ezt erősítette meg, nem igen hiszi, hogy a varrás és a tojások száma között valamiféle összefüggés lenne.

„December 13-án, Luca napján a fiuk, sokszor a legények is gerendát vagy vastagabb dorongot visznek magukkal, és azt beviszik a rokonok, vagy ismerősök családok konyhájába. Ott ráülnek és kórusban mondják: a kotyolás szövegét.

A mondóka befejezése után a gyermekek pénzt, a legények bort kapnak, majd odébb mennek egy házzal."87

86 tikmony, tojás

87 Varga Gy kézirat 1950-es évek.

\section{December 24, Karácsony}

„December 24. Mindenki a legszebb ruhájában, lehetöleg bársonyszoknyába ment a misére. Karácsony elött a Bíró kiparancsu'ta a község kocsiját és elvitte a gyerekeket gyónni Göllébe. Kimé'ték a gyerekeket, amíg nem járt iskolába addig nem ment misére gyalog Göllébe. Ha nagy hó volt akkor lovas hóekével eltolták a havat a földes útról."

„A kis Jézusnak az asztal alá kis széna kévét tettek a háború előtt. Volt, aki az 1960 - as években is vitt az asztal alá szénát. Karácsonyi ünnepekkor felkeresték egymást este a komák. Az őszi munkák után egy kis beszélgetésre vágytak a sógorsággal, komasággal, egyéb atyafisággal."

\section{December 28, Aprószentek}

„December 28-án, karácsony negyedik napján a fiuk füzfavesszőből font korbáccsal járnak házról-házra. Beköszöntőül a szokásos mondókát használják.

Aztán ütni kezdik a korbáccsal a házban talált aszszonyokat, közben egyre mondják:

- Jó sütő-föző légy!

- Jó fonó-varró légy!

- Jó misejáró légy!

- A férjedhez kedves légy!

Kimennek még az istállóba is, ott a lovat, tehenet is megkorbácsolják:

- Jó vemhező légy! Nagy tejelő légy!

Mikor mindenkit megkorbácsoltak, ajándékot kapnak, és tovább mennek.

A fiatalabb férfiak is elmennek korbácsolni, mondókák nélkül. Főleg a komámasszony, a rokon menyecskék, a barátok feleségei kapnak korbácsot, de az utcán talált távoli ismerősöket sem kerülik el.

A korbácsolás mondókája még az 1980-as években elhangzott, akkor még volt fiú, ki járt korbácsolni."88

„A karácsonyi szemét Aprószentek napján, felszórva a gyümölcsfára, hogy jó termés legyen.” „A karácsonyi hulladéknak, szemétnek különben mágikus ereje van."

„Országszerte általánosnak mondható szokás, hogy a gyümölcsfákra szórják, azért hogy jobban teremjenek."89

Összegzésképp, a hagyományok közül már egyes szokásokat nem "gyakorolnak”, azonban a szentelt gyertyához, búzához, barkához, kötődő hagyományok jól ismertek mindenki számára. A szentelés után hazavitt, szentelt gyertya, barkaág, búzaszál becsben van tartva manapság is. Igaz, már nem rózsaszín szalagon függ a falon a gyertya, a búzaszál sem a rag alá van tűzve, hanem a szobában egy polcon kap helyet. Ez nem csupán az értékrend változással, hanem az anyagi javak gyarapodásával is összefügg. Amikor a Biblia, sőt a kenyér is a mestergerendán kapott helyet, hol másutt függhetett volna a gyertya, mint a falon, polcok híján. Van, ami egyszerüsödött a megnövekedett lehetőségek ellenére, a templomba-járás szokásai közül a „misére járó ruha” ünnepélyessége is. Amíg a korábbi években

88 Lanszkiné Széles G. 2007: 169

89 Bálint S.1937: 28 
nagy hangsúlyt fektettek arra, hogy a színek összhangban legyenek az ünneppel, ma már sokan nem is ismerik a színek liturgiáját. A körmenetek is mára a templom köré helyeződtek. A búcsújárás sem gyalog történik. Leegyszerűsödtek az Úrnapi sátrak is, nem fedi hófehér gyolcslepedő, vagy zöld hársfa lomb. Azonban van, ami sokak számára nem változott, munka kezdéskor elhangzik a „Jézus nevébe!”, mint ahogy elhangzott száz évvel ezelőtt is: „Az e’ső kaszavágásná: Jézus nevébe! Én is ugy vótam, ha nekiátam valaminek, mög máig is,... fözni, kapáni...: a Jézus nevében!” 90 „A vallásos szertartásokon való rendszeres részvétel biztosította a rendet az emberek életében, mintegy keretül szolgált. De a vallás tanításai nemcsak az ünnepi szertartásokon hangzottak el. Elkísérték az embert mindennapjaiban is. Mindig tudták, hogy létezik valaki, akit segítségül lehet kérni, akinek hálát lehet adni, a magányban sem kellett, hogy egyedül érezzék magukat." ${ }^{91}$ A gyűjtés bizonyítja, hogy a hagyományok tisztelete és sok elfeledettnek vélt szokás ma is él.

\section{Képek forrása:}

5., 6., 14-16. Kisgyaláni lakosok által rendelkezésre bocsájtott fényképek.

17-28. Hajder Edit által rendelkezésre bocsájtott fényképek.

30. Horváth György által rendelkezésre bocsájtott fénykép.

29. Nyerges Péter által készített fotó.

1-4., 8-13., 31., 32. Lanszki Péter által készített fotók.

7. Lanszki Zsófia által készitett fotó.

\section{Irodalom}

BÁLINT S. 1939: Adatok a magyar búcsújárás néprajzához. Ethnographia, L/3-4. 1939., pp. 193-200.

BÁLINT S. 1937: Népünk ünnepei Az egyházi év néprajza. A Szent István-Társulat Kiadása. Budapest.

BÁLINT S. 1989: Karácsony, Húsvét, Pünkösd. Az Apostoli Szentszék Könyvkiadója, Budapest.

BÁLINT S. 2009: Sacra Hungária Népünk ünnepei. Ős- Kép Kiadó, Budapest.

BIHARI A. És Pócs É. 1985: Képes magyar néprajz. Corvina Kiadó, Budapest.

BOGNÁR S. 2001: Új Ember, 2001. április 29. LVII. évf. 17. (2752.)

EPERJESSY E. 2006: Puszták népe a Zselicben (1900-1950). Mikszáth Kiadó, Budapest.

FEKETE I. 1976: Ballagó idő. Móra Ferenc Ifjúsági Könyvkiadó, Budapest.

FEKETE I. 1972: Tíz szál gyertya. Móra Ferenc Ifjúsági Könyvkiadó, Budapest.

JELI J. 1998: Kölyökparázs. Szerzői kiadás, Pécs.

KIRÁLY L. 2002: Somogyi népszokások I. Kaposvár.

KNÉZY J. 1975: A táplálkozás szokásai és rendszere Gige, Csököly, Rinyakovácsi és Kisbajom belsö-somogyi községekben. A Kaposvári Rippl-Rónai Múzeum Közleményei, Kaposvár pp. 103-118.

KNÉZY J. 2013: Céhes adatok a somogyi pék és mézesbábos mesterekről az 1810-es évektöl 1869-ig. A Kaposvári Rippl-Rónai Múzeum Közleményei, Kaposvár pp. 103-118. 251-260.

LANSZKINÉ SZÉLES G. 2011: Ember és természet viszonya: a határ-, a dülőnevek és a dülö- utak ismeretének tükrében. Acta Scientiarum Socialium Kaposvár University No.34, Kaposvár pp. 111-135.

LANSZKINÉ SZÉLES G. 2007: Kisgyalán története és néprajza. Kiadta a Kisgyalán Községi Önkormányzat, Kaposvár.

LANSZKINÉ SZÉLES G. 2011: Falucsúfolók, szállóigék és a falvak egymás közti divatja. Acta Scientiarum Socialium Kaposvár University No.34, Kaposvár pp. 181-196.

LANSZKINÉ SZÉLES G. 2013: Fonó története és néprajza. Kiadta a Fonó Községi Önkormányzat, Kaposvár.

LANSZKINÉ SZÉLES G. 2013: Életfordulók és közösen végzett munkák ételei és szokásai az 1940-es évektöl napjainkig. A Kaposvári Rippl-Rónai Múzeum Közleményei, Kaposvár pp. 261-298.
LÉVAINÉ GÁBOR J. 1963: Komatál. - Ethnographia LXXIV. Évf. 2. pp. 230-260.

LUKÁcs L. 2014: Szent Vendel tiszteletéröl Somogyban. A Kaposvári Rippl-Rónai Múzeum Közleményei 3. Kaposvár pp. 235-246.

MNL. SML. Szemelvények a közigazgatási iratokból, vegyes számadásokból (1866-1948).

RostA E. És RÁBAI A. 2007: Hiedelmek hagyományok babonák. Korona Kiadó, Budapest.

SELMECZI KovÁcs A. 2014: Nemzeti jelképek a magyar népmüvészetben. Cser Könyvkiadó és a Néprajzi Múzeum, Budapest.

SzABó T. És K. GodA GY. 1984: Somogy megye müemlékjegyzéke. Somogy megyei nyomdaipari Vállalat, Kaposvár.

TÁTRAI Zs. ÉS MoLnÁR E. 1997: Jeles napok, ünnepi szokások. Mezögazda Kiadó, Budapest.

TÉszabó J. 2011: Húsvét Magyar hagyományok. Kossuth Kiadó, Budapest.

VÁRKONYI I. 1984: Somogy megye helységneveinek rendszere. Somogyi Almanach 41. szám. Kaposvár, pp. 3-71.

VÁRKONYI I. 1988: Büssüi tájszótár. Akadémiai Kiadó, Budapest.

VARGA GYULA Kisgyalán története (kézirat) pp. 1-32.

A katolikus egyházi év ünnepei. A magyar parasztság életében ... hunyadilaca.hu/zene/segedanyag/egyhazi_unnepek.pd

Fekete István Múzeum honlapja www.feketeistvanmuzeum.hu/hirek/ szvende/2013.htm Bodó Imre

Kisgyaláni római katolikus templom (müemlék) | Somogyi Érték

somogyiertekek.hu/somogyi.../kisgyalani-romai-katolikus-templommuemlek.html

Keresztjáró napok - Magyar Katolikus Lexikon

lexikon.katolikus.hu ,

Malonyai D.:Amagyar nép müvészete - MEK mek.oszk.hu/01600/01671/ $\mathrm{html} / \mathrm{index} . \mathrm{html}$

Mária-ház - Magyar Néprajzi Lexikon / mek.oszk.hu/02100/02115/ $\mathrm{html} / 3-1561 . \mathrm{html}$ 